\title{
Meios de transporte e desenvolvimento regional no estado do Amazonas: uma análise das microrregiões geográficas do Madeira e do Purus
}

\section{Mean of transport and regional development in the state of the Amazonas: an analysis of the micro-geographical regions of the Madeira and the Purus}

Ronaldo Sérgio da Silva - Mestre em Economia pela Universidade da Amazônia. Doutor em Desenvolvimento Regional - UNISC. Membro da ALASRU - Associação Latinoamericana de Sociologia Rural. E-mail: ronaldosergio3@yahoo.com.br

Rogério Leandro Lima da Silveira - Geógrafo pela Pontifícia Universidade Católica do Rio Grande do Sul, mestre e doutor em Geografia Humana pela Universidade Federal de Santa Catarina. Professor titular e pesquisador do Departamento de História e Geografia, e pesquisador e orientador no Programa de Pós-Graduação em Desenvolvimento Regional - da Universidade de Santa Cruz do Sul. E-mail: rlls@unisc.br

\section{Resumo}

A análise da rede de transporte existente no estado do Amazonas e de sua relação com o desenvolvimento regional visa ampliar o campo de estudo sobre essa temática, não se restringindo a uma abordagem parcial sobre determinado modal de transporte, mas buscando contribuir para o aprofundamento da reflexão teórico e conceitual das questões do desenvolvimento regional e das políticas públicas de transportes. Escolhemos analisar as Microrregiões do Madeira e do Purus, por possuírem os três modais usados no Amazonas, na maioria dos seus municípios. Sinteticamente, concluímos que as microrregiões selecionadas atenderam ao principal propósito dos pioneiros da promoção dos transportes no Brasil na interligação das distantes e isoladas províncias com vistas à constituição de uma Nação-Estado, quando em seus territórios foram implantadas as rodovias federais BR-319 e BR-230, e também aeroportos nos municípios. A expansão das vias de transportes permitiu a intensificação da imigração para novas terras agricultáveis e ampliação da colonização. Isto modificou o modo de vida da população local e aumentou a necessidade da oferta de serviços essenciais à população. Os programas e projetos de transportes não exibiram um conjunto de ações com os mesmos propósitos, e nem uma sobreposição das ações e das políticas, mostrando a divergência de interesses entre o Governo Federal e os agentes econômicos que atuam nestes territórios.

\section{Palavras-chave}

Amazonas. Rede de Transporte. Microrregiões. Políticas Públicas. Desenvolvimento Regional.

\begin{abstract}
The analysis of the existing transport network in the state of Amazonas and its relation to regional development aims to broaden the field of study on this topic, not restricted to a partial approach on a particular transport mode, but seeking to contribute to deepening reflection theoretical and conceptual issues of regional development and transport policies. We chose to analyze the micro-regions of Madeira and Purus, by having the three modes used in the Amazon in most of its municipalities. In summary, we conclude that the selected micro-regions attended the first of the pioneers in the promotion of transport in Brazil in the interconnection of remote and isolated provinces aimed at developing a nation-state when their territories were established in the federal highway BR-319 and BR- 230, as well as airports in the cities. The expansion of transportation routes allowed the intensification of immigration to new lands and expansion of agricultural colonization. That changed the way of life of local people and increased the need for the provision of essential services to the population. The programs and transportation projects did not exhibit a set of actions for the same purposes, and not a superposition of the actions and policies, showing the divergence of interests between the federal government and the economic agents that operate in these territories.
\end{abstract}

\section{Keywords}

Amazon. Transport Network. Micro-regions. Public Policy. Regional Development. 


\section{INTRODUÇÃO}

O fato de a densidade demográfica do estado do Amazonas ser baixa, aproximadamente 2,21 habitantes por $\mathrm{km}^{2}$ em 2010 (IBGE, 2010), e de muitos dos municípios e das suas localidades possuírem precárias ligações de infraestrutura de transporte - que vão desde as rodovias mal conservadas ou de sua inexistência, hidrovias intermitentes e sujeitas às sazonalidades dos rios e pistas de pouso ou aeroportos sem adequados instrumentos para voos -, representam obstáculos para o cumprimento das políticas públicas voltadas à promoção do desenvolvimento regional, para o incremento da divisão territorial do trabalho, e para a plena circulação da produção, mercadorias e das pessoas.

Tal constatação serve como elemento norteador para abordarmos neste artigo a relação entre as políticas públicas de transporte, a dinâmica de funcionamento da rede de transportes e o processo de desenvolvimento regional no estado do Amazonas.

Metodologicamente, optamos por realizar essa abordagem analisando como esse processo se apresenta nas Microrregiões Geográficas do Madeira e do Purus. Ajudou-nos na escolha dessas duas microrregiões a nossa experiência profissional na Amazônia, principalmente no Amazonas, quando da construção, ampliação e manutenção de aeroportos na região, que, para estes propósitos exigiam conhecimento logístico das vias de transporte na Amazônia, para mobilização de insumos e transporte de pessoal. Por ocasião da nossa pesquisa de campo, também realizamos observações nas cidades situadas nos entroncamentos dos modais de transporte aeroviário, rodoviário e hidroviário, e entrevistas com usuários dos meios de transporte, proprietários de embarcações que transportam cargas e pessoas, funcionários de empresas de transporte aéreo e donos de transportes terrestres, que utilizam sistematicamente as rodovias que passam nos municípios/cidades. ${ }^{1}$ Escolhemos analisar as Microrregiões do Madeira e do Purus, por serem as regiões que possuem o maior número de municípios atendidos por rodovias federais, pelos principais rios e aeroportos implantados

1 A pesquisa de campo envolveu a realização de viagens em barco de linha que transportam pessoas e cargas nos rios Madeira e Purus. Num total de 30 dias, percorrermos o trajeto de Manaus até Humaitá pelo rio Madeira; seguimos a viagem na carroceria de caminhão, de Humaitá até Lábrea, e retornamos a Manaus de barco, pelo rio Purus. Nestas viagens, fomos entrevistando os passageiros, dentre eles, professores, comerciantes e até mesmo proprietários dos barcos e funcionários. As entrevistas versavam sobre os meios de transportes, os modais em uso, a satisfação dos passageiros, os problemas enfrentados pelos professores e pelos comerciantes. Nos trajetos, também fomos observando o modo de vida da população ribeirinha, urbana, rural, além de documentarmos em fotografias algumas cenas do cotidiano da população das microrregiões selecionadas. 
nos seus municípios, bem como para analisar, em cada uma delas, como ocorre a relação estabelecida entre a rede de transporte e o desenvolvimento regional, e, também, neste caso, como se apresenta a implementação das políticas públicas que visaram e viabilizaram as vias de transporte.

O presente artigo está organizado em quatro partes. Inicialmente, apresentamos de modo sucinto algumas das principais características da organização socioespacial e da formação e dos usos do território em cada uma dessas microrregiões. Em um segundo momento, abordamos o conceito e a concepção de desenvolvimento regional, que orienta nossa análise sobre este aspecto no estado do Amazonas, notadamente nas microrregiões selecionadas. Em um terceiro momento, analisamos como se caracterizam os meios de transporte existentes nas microrregiões selecionadas, as políticas públicas de transporte adotadas e sua relação com o processo de desenvolvimento regional. Por fim, analisamos as características e tendências atuais dos agentes sociais e seus principais usos do território, bem como do funcionamento e planejamento dos meios de transporte existentes e seus reflexos no processo recente de desenvolvimento regional nas microrregiões do Madeira e do Purus.

\section{CARACTERÍSTICAS DAS MICRORREGIÕES DO MADEIRA E DO PURUS}

Considerando que o estado do Amazonas possui várias regionalizações e sub-regionalizações, criadas a fim de buscar resolver seus problemas administrativos, notamos que há uma falta de convergência entre os diversos atores da administração, o que pode influenciar negativamente na otimização das ações para o atendimento da demanda de necessidades da população.

E um dos empecilhos existentes é que as diversas regionalizações e subregionalizações se sobrepõem territorialmente, induzindo-nos a afirmar que no estado do Amazonas existe uma territorialização para as políticas públicas, uma para o desenvolvimento e outra para a governança, que, segundo Delgado et al. (2007), são abordagens numa perspectiva de intervenção governamental. São ações clássicas na Amazônia, que produziram reflexos no estado do Amazonas.

Desta forma, na tentativa de evitar um viés destorcido da aplicação das políticas públicas de transporte que foram pensadas ou que tiveram reflexos no estado do Amazonas e nas microrregiões selecionadas do Madeira e do Purus, adotamos, de agora em diante, o conceito de microrregião geográfica do IBGE (1990, p. 7-8), destacando a importância do impacto da expansão capitalista que vem se apropriando do território. 
Figura 1: Amazonas: microrregiões geográficas do Madeira e do Purus.

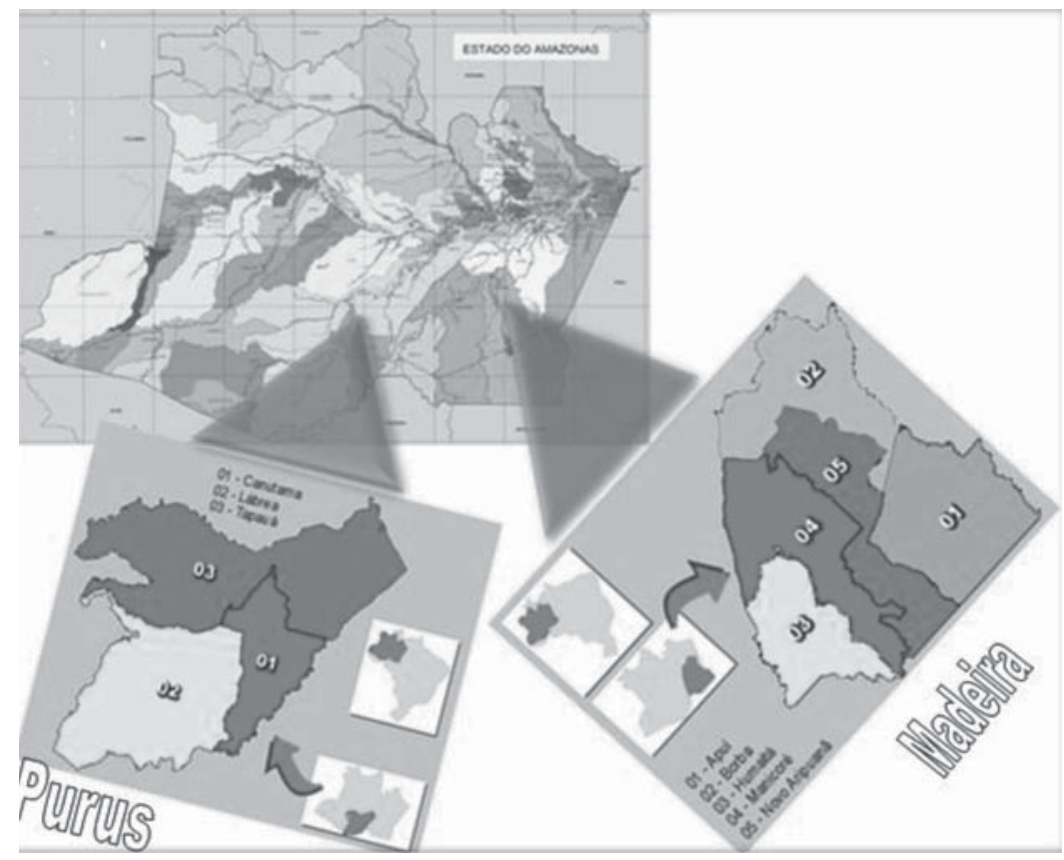

Fonte: Silva (2011). Adaptação do autor.

Então, essa é, a nosso ver, a escala mais adequada para a articulação e mediação das diferentes políticas, diante das considerações aqui apresentadas, na premissa de que a questão do desenvolvimento das microrregiões selecionadas está ligada à forma como o Estado atuou no espaço nacional a partir de 1930, e suas consequências nas microrregiões geográficas do Madeira de do Purus.

As microrregiões do Madeira e do Purus, como parte da história construída pelos homens e palco dos diversos arranjos institucionais, foram contempladas com a construção das rodovias BR-319, BR-317, BR-230 (Transamazônica) que, em conjunto com algumas rodovias estaduais (AM-364 e AM-356), interligam cerca de 60\% das sedes municipais do estado do Amazonas com a capital, Manaus, e com o restante do país, constituindo-se na área amazônica mais bem servida por estradas de rodagem. Estes objetos (rodovias) surgiram no território com o advento de diversos planos governamentais, dentre eles, o de Integração Nacional (IBGE, 1991).

Mas as microrregiões possuem condicionantes naturais, como as chuvas, o clima e as especificidades do solo, que representam claras dificuldades para a implantação e manutenção das rodovias, impossibilitando uma melhor condição de uso pela população e pelos diversos atores que atuam em seus territórios. 


\subsection{OCUPAÇÃOTERRITORIALEARTICULAÇÃODASMICRORREGIÕES DO MADEIRA E DO PURUS}

A mesorregião onde se encontra as microrregiões do Madeira e do Purus já era percorrida por desbravadores no século XVII, e a ocupação definitiva se deu a partir do século XVIII, por bandeirantes paulistas em busca de ouro e também por "Entradas", que, partindo de Belém, participavam do comércio da prata andina. As Entradas tinham também como objetivo ligar a Amazônia às minas matogrossenses e desbravar a região (IBGE, 1991).

No século XVIII, os pioneiros que vieram pelo rio Amazonas e outros desbravadores originados do Sudeste do país, utilizando-se dos rios que possuem nascentes em Mato Grosso e Rondônia, chegaram ao sul amazonense e se instalaram nas áreas conhecidas hoje como as microrregiões do Madeira e do Purus, à procura de ouro e, mais tarde, para a exploração de produtos extrativos, entre eles a borracha.

De acordo com o Governo do Estado do Amazonas (2010), no rio Purus, o povoamento civilizado iniciou muito mais tarde do que em outras zonas do Amazonas. O primeiro núcleo de povoamento organizado na zona do rio Purus foi, provavelmente, a Missão de São Luiz Gonzaga, fundada em 1854, por Frei Pedro Ceriano, com índios Muras, Cauinicis, Mamuris, Jamadis, Purupurus etc. Em 1871, começaram a chegar os nordestinos, na terra firme do Amaciari, hoje Lábrea, trazidos pelo Coronel Antônio Rodrigues Pereira Lábrea.

O acesso aos municípios da microrregião do Purus se faz essencialmente por via fluvial e aérea. A distância em linha reta da sede dos municípios à capital do estado do Amazonas é: Canutama, 620 km; Lábrea, 610 km; e Tapauá, 450 km. Já por via fluvial, as distâncias aumentam sobremaneira devido à sinuosidade dos rios. Assim, temos: Canutama, 1.274 km; Lábrea, 1.672 km; e Tapauá, 1.228 km. Os municípios de Canutama e Lábrea possuem acesso à capital, Manaus, também através de rodovias, utilizando-se das BRs 319 e 230. O tempo de viagem pelas rodovias é condicionado pelas condições das estradas e das chuvas, e a região permanece praticamente dependente da via fluvial, com qualidade de navegação inferior a do Madeira. Apenas a cidade de Lábrea possui ligação rodoviária, porém antiga e precária, como constatado em nosso trabalho de campo.

Resumidamente, a microrregião do Purus possui uma área absoluta de $187.372,9 \mathrm{~km}^{2}$, e o percentual da área em relação ao estado do Amazonas é de 11,93 \%. Os municípios que a compõe são: Canutama, Lábrea e Tapauá. 
As primeiras penetrações pelo rio Madeira datam nos registros de 1637, quando da expedição de Pedro Teixeira, ligando Belém do Pará a Quito, no Equador. Habitavam na região, primitivamente, os índios: Toras, Barés, Muras, Urupás, Araras e outros.

Em meados do século XIX, a Freguesia de Nossa Senhora do Bem de Humaitá foi fundada pelo comendador José Francisco Monteiro. Humaitá tornou-se o mais importante centro urbano da microrregião, em virtude de sua localização geográfica, em meio a um entroncamento rodo-fluvial formado pelas rodovias BR-319 (trecho Porto Velho-Manaus), BR-230 (Transamazônica) e pelo rio Madeira. A cidade dispõe dos principais serviços urbanos (IBGE, 1991, p.49).

A criação do município de Apuí, em 1988, que fica às margens da Transamazônica (BR-230), "representou uma tentativa de expansão da atividade agrícola, mas a possibilidade de transporte e a irregularidade de tráfego e as grandes distâncias para atingir os centros consumidores transformaram a agricultura em modesta expressão econômica", embora seja a segunda área produtora do estado (IBGE, 1991, p.48-49).

$\mathrm{O}$ acesso aos municípios da microrregião do Madeira se faz por via fluvial, rodoviária e aérea. A distância em linha reta da sede dos municípios à capital, Manaus, é: Apuí, 460 km; Borba, 150 km; Humaitá, 580 km; Manicoré, 333 km; e Novo Aripuanã, 255 km. Por via fluvial, a distância é: Borba, 215 km; Humaitá, 959 km; Manicoré, 421 km; e Novo Aripuanã, 300 km. O município de Apuí não possui ligação fluvial - e sim rodoviária, através do uso das BR-230 e 319.

A microrregião do Madeira tem uma área de 221.036,6 km², ocupando 14,07 \% do estado do Amazonas. Seus municípios são: Apuí, Borba, Humaitá, Manicoré e o município de Novo Aripuanã (SEPLAN-AM, 2009).

Até a metade da década de 1980, conforme IBGE (1991), a coleta da borracha, da madeira e da castanha-do-pará ainda prevalecia; e só mais recentemente a economia local se modificou, apoiando-se não apenas no extrativismo vegetal, mas também na extração de ouro e de cassiterita, na regularização da pesca em colônia, no estabelecimento das fazendas de gado nos antigos seringais e no surgimento dos cultivos de café, arroz e soja. Estes são apenas alguns exemplos da nova dinâmica da região, que faz de Porto Velho um centro importante, com forte influência regional e com estreita relação com as microrregiões selecionadas.

As articulações através das rodovias beneficiaram as microrregiões do Madeira e do Purus com a construção da BR-319. A articulação das microrregiões se completa com todos os modais possíveis para a região - as hidrovias, as rodovias e as aerovias. As aerovias, com as linhas aéreas regionais, interligam as suas sedes municipais às cidades de Porto Velho e de Manaus e, através destas, com as demais regiões do país. 

uma análise das microrregiões geográficas do Madeira e do Purus

Enquanto o Vale do rio Madeira dispõe da via rodoviária e da via fluvial para as suas comunicações com o estado e com o país, o Vale do rio Purus ainda tem na via fluvial o principal meio de comunicação, embora em ambas as microrregiões existam ligações por linhas aéreas regionais, mas tal transporte é restrito, devido ao alto custo de suas tarifas.

\section{REFLETINDO SOBRE O DESENVOLVIMENTO REGIONAL}

Aqui utilizamos ideia de desenvolvimento de forma mais ampliada, buscando superar a tradicional ideia de desenvolvimento econômico, associada ao processo de crescimento econômico e, via de regra, verificada através de indicadores quantitativos como renda, nível de emprego, capacidade produtiva e população.

Assim, analisamos o desenvolvimento regional de acordo com os julgamentos de Frey e Wittmann (2006), Becker (2001), Ferreira (2002), Boisier (1995) e Riella (2006).

Julgando como insuficiente o desenvolvimento de uma região baseado no crescimento econômico, Frey e Wittmann (2006) consideram que o desenvolvimento regional é um processo de acumulação que tem lugar no espaço de uma dada região. Promove uma mudança social sustentável, com o propósito de progresso permanente de uma comunidade e seus membros.

Não se esquecendo das ilações econômicas à concepçãode desenvolvimento, e que ainda mostra suas marcas sobre os mais diversos territórios, Becker (2001), citando Polany (1980), diz que

[...] na dinâmica do desenvolvimento atual, observa-se duas ordens de determinação: (1) uma, definida pelo primado do econômico, devastando nações e regiões; (2) a outra, perseguida pelas sociedades regionais e nacionais, reagindo à devastação e buscando proteger-se, defendendo suas sociedades da destruição. Dessa forma, o movimento do econômico (a ação econômica) e o contra movimento do social (a reação do social) compõem movimentos contraditórios por natureza (POLLAN, 1980 apud BECKER, 2001, p.19).

A esfera política é o espaço primordial na mediação das transformações históricas efetivas do desenvolvimento regional. A transformação, para ser observada, de acordo com Becker (2001), precisa considerar a esfera econômica do desenvolvimento regional, que envolve: trabalho, natureza e organização produtiva enquanto mercadoria, ou melhor, enquanto produção e reprodução do capital; e a esfera social e ambiental, que engloba: trabalho, natureza e organização produtiva enquanto vida, ou melhor, enquanto produção e reprodução da vida. 
Numa região tão vasta como o estado do Amazonas, mesmo nas suas microrregiões, e de população rarefeita, analisar, nestes termos citados por Becker, o processo efetivo do desenvolvimento até então apresentado pelo Amazonas, pode apontar qual o viés que foi predominante, em função da especificidade do território e das políticas públicas.

Importante destaque para o desenvolvimento regional, e que colaborará com este trabalho, faz Becker (2001), ao dizer que:

[...] o desenvolvimento regional deve ser entendido como um processo de transformações econômicas, sociais e políticas, cuja dinâmica é impressa desde de dentro e por iniciativa própria dos agentes locais, manifesta nas mudanças estruturais ou qualitativas que um desenvolvimento regional sofre a partir de alterações endógenas (BECKER, 2001. p.40).

A antiga fórmula de se fazer desenvolvimento, segundo Becker (1998), consistia em considerar que a única possibilidade de desenvolvimento de uma determinada região (ponto na rede) era servir aos interesses dos conglomerados transnacionalizados, concedendo-lhes todo tipo de facilidades. Ao considerar esta fórmula propicia uma concentração de investimentos e renda que acabava por gerar crescentes desequilíbrios regionais e desigualdades sociais.

Para Ferreira (2002), o processo de desenvolvimento do território deve visar o desenvolvimento econômico e social e enfatizar, dentre outras coisas, o aumento da autonomia local; capacidade local de gerar renda e excedentes econômicos; foco na necessidade inadiável de inclusão social, com respectiva diminuição da exclusão econômica de contingentes da população; e maior envolvimento e conscientização do papel da base de recursos naturais no processo de desenvolvimento regional, instigando na população a responsabilidade pela gestão proativa do potencial natural, visando à racionalização da relação custo ambiental e benefício econômico.

A contribuição de Boisier vem no sentido de esclarecer que:

[...] a planificação do desenvolvimento regional é, antes de mais nada, uma atividade societária, visto ser uma responsabilidade compartilhada por vários atores sociais: o estado, evidentemente, por razões várias e conhecidas, e a própria região, enquanto comunidade regional, polifacética, contraditória e difusa, por vezes, mas comunidade, enfim, locacionalmente específica e diferenciada. Sem a participação da região como um verdadeiro ente social, o planejamento regional consiste apenas - como mostra a experiência histórica - em um procedimento de cima para baixo para distribuir recursos, financeiros ou não, entre espaços erroneamente chamados de regiões (BOISIER, 1995, p. 47, 48). 

uma análise das microrregiões geográficas do Madeira e do Purus

Esta contribuição, junto com as demais, mostra que é importante observar como as políticas públicas que fizeram referências às vias de transporte foram pensadas e chegaram a ser implementadas para o Amazonas, pois o Estado, nesta vasta área geográfica e de baixa densidade demográfica é, na maioria das vezes, “a própria região" e não "participando com um verdadeiro ente social”. Incluem-se nestes fundamentos os embutidos na globalização - um forte fator exógeno que incide nas comunidades locais e caracterizando o processo de desenvolvimento contemporâneo.

Além do processo de globalização que inevitavelmente alcança o estado do Amazonas, interferem no processo de desenvolvimento, como condicionantes, as configurações históricas regionais, sociais e físico-naturais específicas de cada caso, as quais se projetam casualmente sobre o processo de desenvolvimento regional, inclusive sobre a sua dinâmica atual.

Riella (2006, p. 272) diz que o desenvolvimento tem por base o espaço local e o patrimônio sociocultural das comunidades. Temos, a partir desta observação, que o desenvolvimento tem sua raiz no espaço local que, segundo Riella (2006), é um território, uma comunidade, um município ou região onde se expressam os direitos da cidadania e se realizam as identidades particulares, ensejando, quando articuladas, solidariedade e desenvolvimento inclusivo das potencialidades econômicas locais.

No território, de acordo com Riella, desenvolvem-se as relações específicas, superando a dicotomia entre o rural e o urbano e estabelecendo articulações internas de respeito e valorização da diversidade e de acordos solidários de cidadania, com vistas ao desenvolvimento sustentável. Estas potencialidades constituem o patrimônio socioeconômico e cultural que expressa a capacidade de organização que a comunidade possui, a fim de mobilizar recursos.

O desenvolvimento regional, no nosso entendimento, tem, então, no local, a sua origem. Conforme revela Riella (2006), o desenvolvimento local pode ser concebido apenas no seu veio de cidadania, sendo, neste caso, necessário compreender suas potencialidades e seus contributos cívicos, como participação local em atividades multifacetadas: cultura, economia, política, religiosidade, social etc.

A promoção do desenvolvimento de regiões vulneráveis, aqui consideradas por nós como as de baixa densidade demográfica e dependência exclusiva do Estado para suprir suas necessidades, deve criar condições para que as atividades econômicas existentes e/ou previstas possam levar à melhoria da qualidade de vida e ao aumento da competitividade local. Estes fatores pressupõem a existência de uma integração territorial, pois é o que preconiza a política nacional de integração e desenvolvimento regional. 
O desenvolvimento regional do estado do Amazonas está intimamente relacionado à cooperação dos distintos modos de transporte, para maximizar a realização de uma cadeia completa de interações sociais que dependem da mobilidade, o que para Joignaux et al. (2007), o tratamento em separado traz a marca do divórcio entre o território e suas redes, que é uma marca difícil de reverter a curto e médio prazos.

De acordo com Joignaux et al. (2007), novas dinâmicas territoriais emergem e elas afetam as necessidades de transporte ou, mais amplamente, o deslocamento de pessoas, bens e informações. Isso se refere à nova coordenação e interação necessária para a produção, troca e mudanças de estilos de vida e, portanto, da utilização do espaço.

A estratégia de desenvolvimento territorial baseada exclusivamente na oferta de infraestrutura pode ter apenas um efeito muito pequeno, pois o desenvolvimento é mais uma dinâmica que converge os elementos já existentes e muitas vezes intangíveis, e os que são criados (JOIGNAUX et al., 2007).

Além dos pontos qualitativo que geralmente são intangíveis para se compreender o desenvolvimento, como os mencionados ao longo de todo este artigo, optamos por apresentar dados elaborados pela Federação das Indústrias do Estado do Rio de Janeiro ${ }^{2}$, Assessoria de Pesquisas Econômicas (FIRJAN³ sobre o emprego, educação, saúde e renda dos municípios brasileiros, dos quais destacamos os relacionados ao estado do Amazonas especificamente dos municípios das microrregiões do Madeira e do Purus, para 2007 (Figura 2).

$\mathrm{Na}$ microrregião do Madeira, o município de Apuí foi o que apresentou a melhor posição no ranking do IFDM, em 2007. Ocupou o quinto lugar no ranking estadual e no nacional ficou em $3487^{\circ}$ lugar. A saúde e a educação foram as que mais contribuíram para a classificação do município.

Em segundo lugar na microrregião ficou o município de Humaitá, que no ranking estadual ocupou o $6^{\circ}$ lugar, e no nacional em $3727^{\circ}$ lugar. A saúde e a educação foram responsáveis pela classificação de Humaitá.

\footnotetext{
2 É importante destacar que o índice FIRJAN utilizado para verificar o desenvolvimento municipal é chamado de IFDM. Varia de 0 até 1 , sendo que quanto mais próximo de 1 , maior será o nível de desenvolvimento da localidade, o que permite a comparação entre municípios ao longo do tempo. Neste sentido, estipularam-se as seguintes classificações: municípios com IFDM entre 0 e 0,4 são considerados de baixo estágio de desenvolvimento; entre 0,4 e 0,6, de desenvolvimento regular, entre 0,6 e 0,8, de desenvolvimento moderado; e entre 0,8 e 1,0, de alto desenvolvimento (FIRJAN, 2010).

3 Emprego e renda, Educação e Saúde constituem as três esferas contempladas pelo IFDM, todas com peso igual no cálculo para determinação do índice de desenvolvimento dos municípios brasileiros. Fonte: http://www.firjan.org.br/data/pages/2C908CE9229431C90122A3B25FA5 34A2.htm.
} 

uma análise das microrregiões geográficas do Madeira e do Purus

O município de Novo Aripuanã, o terceiro da microrregião, ocupou o $14^{\circ}$ lugar no estado e o $4353^{\circ}$ lugar no nacional. Manicoré ficou em $29^{\circ}$ no ranking estadual e $5060^{\circ}$ no nacional. Por último na microrregião ficou o município de Borba, que ocupou o $36^{\circ}$ lugar no ranking estadual e o $5147^{\circ}$ no nacional. $\mathrm{Na}$ microrregião do Purus, o município de Canutama foi o que ocupou a melhor posição no ranking, ficando em $11^{\circ}$ lugar no estadual e $4015^{\circ}$ no nacional. A educação foi a que mais contribuiu para a classificação do município. O município de Tapauá ficou em $31^{\circ}$ lugar no estadual e em $5077^{\circ}$ lugar no nacional. Já o município de Lábrea foi o último classificado das duas microrregiões, ficando no $47^{\circ}$ lugar no ranking estadual e $5314^{\circ}$ no nacional.

O IFDM mostra que na microrregião do Madeira a situação é um pouco melhor do que a do Purus e os municípios se situam entre os índices 0,30 e 0,46, sendo que os melhores classificados são Humaitá, com 0,439 e Novo Aripuanã com 0,454, ambos com quase a metade do de Coari.

Através do IFDM, podemos ver (Figura 2) que os municípios da microrregião do Purus obtiveram índices que se situam entre 0,22 e 0,46 em 2007. O melhor resultado fica com o município de Canutama, com 0,445.

$\mathrm{Na}$ Figura 2, pode-se visualizar melhor o comportamento das microrregiões do Madeira e do Purus, além de compará-las com as demais microrregiões do estado do Amazonas.

Figura 2: Índice Firjan de Desenvolvimento Municipal - 2007.

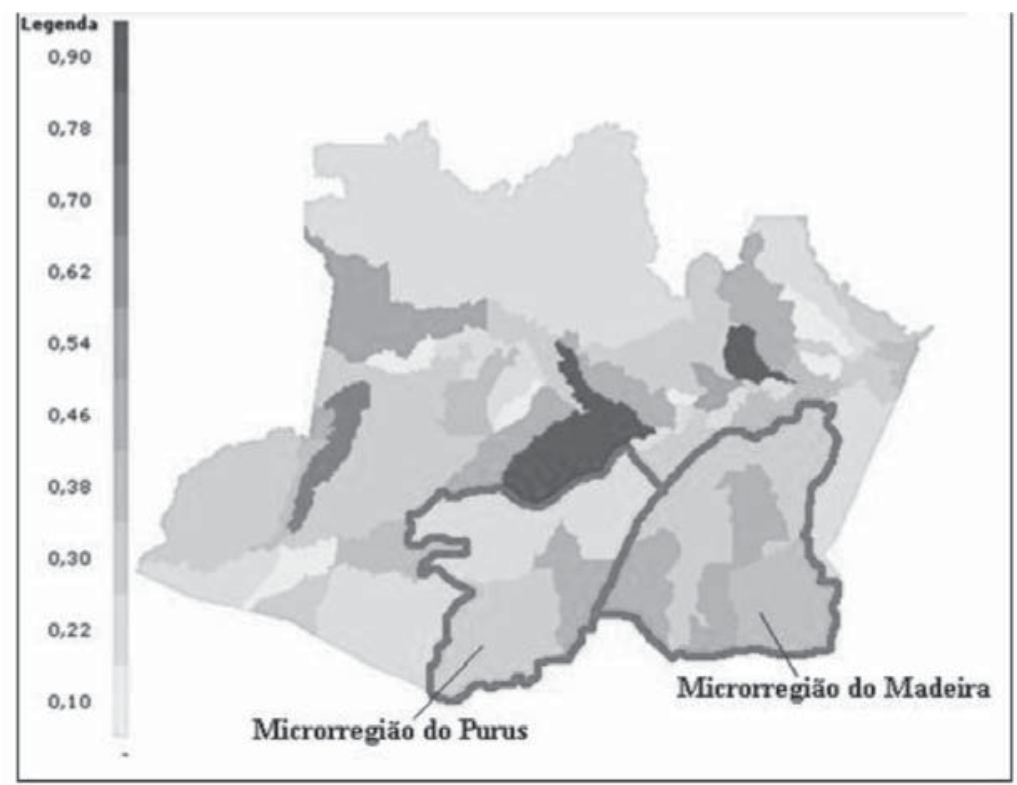

Fonte: FIRJAN (2010) e IPEA (2010). 
Observamos que, mesmo internamente, nas microrregiões o descompasso é enorme, pois na microrregião do Madeira exitem municípios bem classificados no ranking estadual, como Apuí e Humaitá, e também municípios ocupando uma posição mediana no estado, mas com péssima classificação em relação ao ranking nacional, como é o caso de Borba.

Entre as duas microrregiões selecionadas, a do Madeira apresenta municípios com melhores indicadores tanto no âmbito estadual quanto nacional, mas nada que deixe os gestores da administração despreocupados. Os índices mostram que a imensidão do território destas microrregiões exige esforços para que se avance no ranking, desenvolvendo a saúde, a educação e, consequentemente, aumentando o emprego e a renda.

\section{MEIOS DE TRANSPORTE E POLITICAS PÚBLICAS DE TRANSPORTES NAS MICRORREGIÕES DO MADEIRA E DO PURUS}

A discussão sobre o papel do planejamento, quando se projetou, através da construção das rodovias federais, a integração territorial da Amazônia, desmistifica as reais intenções do planejamento como promotor do desenvolvimento regional, pois transpareceu o caráter ideológico quanto ao atendimento dos ideais do poder central, beneficiando os polos industriais e ao Centro-Sul-Sudeste e Nordeste do país, inclusive com as migrações de nordestinos e de sulistas.

A construção de rodovias no estado do Amazonas se realizou principalmente nas microrregiões geográficas do Madeira e do Purus, em maiores extensões; em outras microrregiões em menor extensão; e em algumas nem foram contempladas.

Compartilhando do que expomos, Conceição e Rocha (2009) dizem que a ideologia do desenvolvimento traduziu os interesses incluídos na agenda da CEPAL, de uma industrialização que atingisse áreas consideradas tradicionais, atrasadas, que precisavam se desenvolver.

O argumento chave da teoria cepalina é a existência do desenvolvimento desigual que, para Lemos (2004), é caracterizado por forças econômicas de atração e repulsão, atuando no espaço de forma desequilibrada, por meio de um processo circular cumulativo. As forças de atração favorecem uma região em detrimento de outra, estabelecendo-se um processo de concentração de fatores e de produção de bens no espaço - o centro -, cujas relações de troca com a região desfavorecida - a periferia - recria a dinâmica centro-periferia. Esta foi a relação estabelecida pelas políticas de transporte ao implantar as rodovias federais, a melhora das hidrovias e a malha de aeroportos na Amazônia, uma relação de 
dependência visível também no interior do estado do Amazonas, inclusive entre as microrregiões selecionadas.

Como as rodovias federais que foram implantadas nos territórios das duas microrregiões selecionadas encontram-se paralisadas quase em sua totalidade, desde a década de 1980 a dinâmica dos fluxos está, em sua maioria, sendo condicionada pelos rios Madeira e Purus.

A construção e dinamização das rodovias buscavam beneficiar a capital do Amazonas, pois estava presente nas concepções de planejamento do Estado a relação com a teoria de Perroux (1967), que estabelecia que a presença de uma indústria motriz atraísse outras indústrias, provocando a concentração de capitais, criando um polo dinâmico de uma dada região, que no caso do Amazonas seria a Zona Franca de Manaus.

Esse polo, por sua vez, na concepção de Perroux (1967), provocaria profundas mudanças sociais, à medida que aumentasse a renda per capita, sendo chamado de polo de desenvolvimento. Os polos de desenvolvimento seriam às vezes espontâneos, mas, na maioria das vezes, planejados; e não existiriam como unidades isoladas, mas estariam ligados à sua região pelos canais por onde se propagam os preços, os fluxos e as antecipações, constituindo elos. Estes polos se originariam através da instalação de uma indústria motriz, de efeito de arraste, que com sua força centrípeta atrairia outras indústrias (ANDRADE, 1978 apud CONCEIÇÃO; ROCHA, 2009).

Mais uma vez, o modelo importado não se concretizou plenamente no estado do Amazonas. Percebemos que as microrregiões mais favorecidas são as próximas a Manaus. Atribuímos o não êxito às dimensões geográficas do próprio estado e as particularidades dos modais de transportes, pois até mesmo as políticas públicas, desde 1968, atribuíam a Porto Velho o atendimento aos municípios mais próximos, o que deveria ser normalmente atribuído ao estado do Amazonas. Estas medidas atingem diretamente as microrregiões do Madeira e do Purus.

Este centro de influência, conforme constatado em trabalho de campo, alcança todos os municípios das microrregiões do Madeira e do Purus, até mesmo chegando a Anori, Beruri e Codajás, dentre outros.

Mas nem todos os bens e serviços provêm de ou são atendidos por Porto Velho, o que faz com que o estado do Amazonas se faça presente, mesmo precariamente, pois os municípios das microrregiões, com população rarefeita, que subsiste do extrativismo e de pequenas agriculturas, como nos diz Confalonieri (2005), sofrem com o desenvolvimento desigual, exigindo outras formas de intervenções setoriais para atendimento à saúde, educação, indústria, e outras de ordem infraestrutural, inclusive sanitária, através de um esforço interministerial de coordenação transversal de políticas sobre o território. 
No Amazonas, o que se vê é que a utilização da hidrovia está cada vez mais incrementada, tanto na otimização das embarcações e sinalizações dos rios, quanto na tecnologia e melhoramento dos portos do interior do estado. Os rios permitem o transporte rodoviário/fluvial, onde os semirreboques de cargas naveguem sobre balsas. As cargas também podem sere transportadas sobre o convés e nos porões das balsas - cargas sólidas e líquidas, respectivamente. Uma modalidade que persiste nos rios do Amazonas são os armazéns flutuantes, com capacidade de carga de 28.000 toneladas, em comboios de 12 balsas. Em Manaus pode-se observar a intermodalidade fluvial e marítima (BERTOLINI, 2007).

As condições naturais, especialmente a grande extensão de vias navegáveis, fazem com que o transporte hidroviário seja tomado como ponto de referência básico para organização da rede de transportes da Amazônia.

As construções dos aeroportos no estado do Amazonas foram influenciadas pelos rios, e eles estão sempre próximos dos mesmos (Figura 3).

Figura 3: Proximidades dos aeroportos e dos rios.

Aeroporto de Canutama

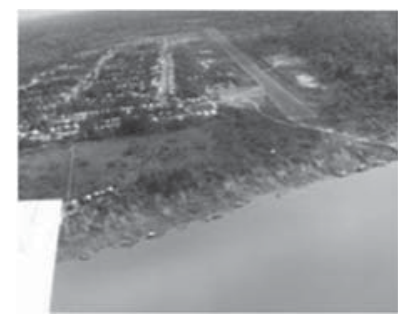

Aeroporto de Tapauá

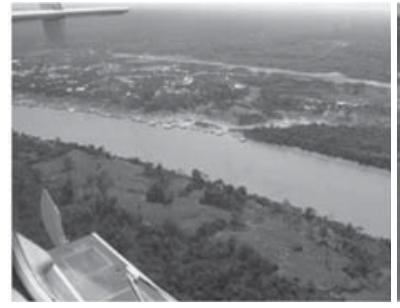

Aeroporto de Manicoré

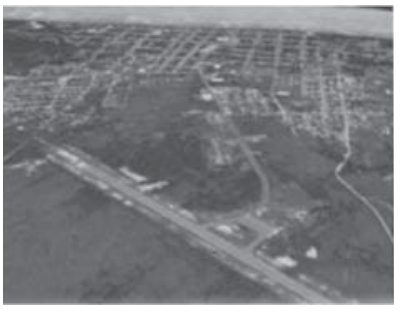

Fonte: Walter Filho (2010); Jelényi (2010).

Assim, as demais modalidades de transporte são chamadas a integrarse com o sistema hidroviário e a complementá-lo. Como exemplo, podemos citar o transporte de soja, que parte do Norte de Mato Grosso, entra no Amazonas e segue destinos internacionais. Além das opções exclusivas, existe a intermodalidade, mesclando-se o transporte terrestre com o fluvial e, em alguns casos, com o aéreo. Considerando que nenhum dos modais possui condições adequadas de trânsito, a escolha tende a levar em consideração todos os custos socioeconômicos ambientais envolvidos no processo de adequação das vias.

Barbosa (2008) aponta as capacidades de transportes e os diversos custos por modais, confirmando a vantagem absoluta do modal hidroviário.

O transporte aéreo demanda os maiores custos operacionais e apresenta elevado consumo de combustíveis, que varia conforme o porte da aeronave, depende das condições atmosféricas e causa poluição atmosférica e sonora. 

uma análise das microrregiões geográficas do Madeira e do Purus

Em nossa pesquisa de campo detectamos que em setembro de 2009, o custo para se transportar uma tonelada de carga no estado do Amazonas era em torno de $\mathrm{R} \$ 2.500,00$, volume que a maioria dos aviões que atendem aos municípios do estado não comporta. É um modal muito limitado, no que se refere ao transporte de cargas e pessoas.

Uma aeronave que comportaria cinco passageiros e mais três pessoas da tripulação, tinha o valor de passagem entre Lábrea e Humaitá de R \$ 450,00 por pessoa. A distância entre Lábrea e Humaitá é de $226 \mathrm{~km}$ por rodovia. Entre Lábrea e Porto Velho (RO), o valor era de R \$150,00 por passageiro.

Em razão dos problemas enfrentados por terra e água, Maranhão (2010) afirma que a distribuição de cargas na Região Norte por transporte aéreo vem ganhando força como alternativa, ainda que isso resulte em despesas maiores. Num percurso de aproximadamente 1.000 quilômetros, que vai de Manaus até Parintins, por exemplo, a entrega de uma encomenda de $100 \mathrm{~kg}$ realizada por avião custa 2.000 reais, o equivalente a 20 vezes o valor cobrado no transporte fluvial. Muitas vezes, porém, a agilidade do serviço compensa essa diferença de preço.

Em relação às aerovias, apesar de existirem várias cobrindo todo o estado, alguns municípios são atendidos sistematicamente pelas companhias aéreas; e os demais, por aviões da Força Aérea, com finalidades específicas e não regulares.

Para melhor entender como os tempos de transportes na Amazônia são diferenciados, e mesmo assim as hidrovias mantêm sua importância, apresentamos na Figura 4 as diferenças dos tempos dos meios de transportes.

Figura 4: Tempo de deslocamento dos transportes na Amazônia.

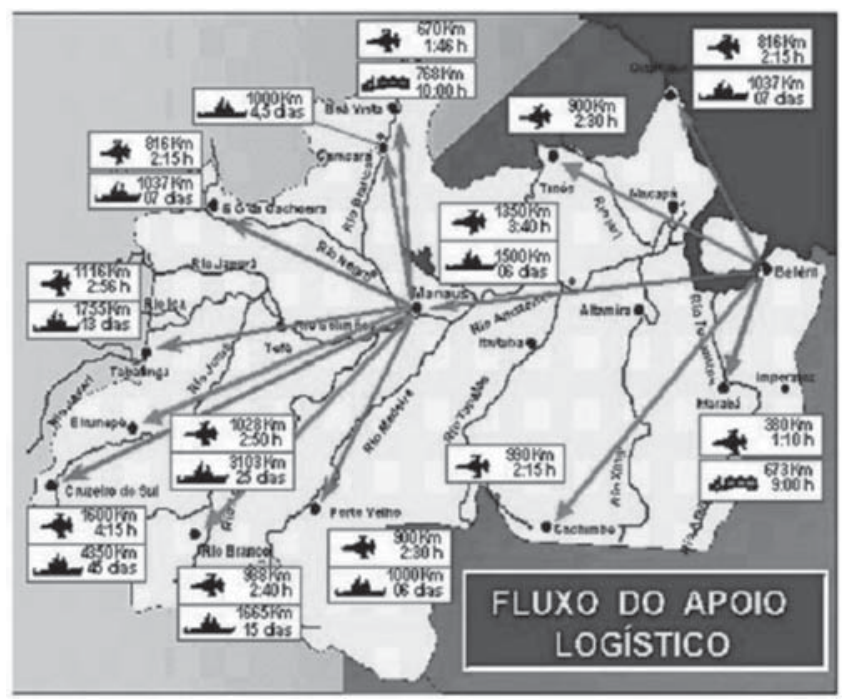

Fonte: COMARA (1996) apud Silva (2003). 
Observamos no trabalho de campo que a hidrovia do Madeira exige das embarcações um tempo de seis dias para que se realize o trajeto entre Porto Velho, no Estado de Rondônia, até Manaus, no Amazonas. Este trajeto percorrido por aviões poderia ser enormemente reduzido, mas a capacidade de carga transportada não seria a mesma, devido às limitações das próprias aeronaves. Isto sem falar no custo do transporte, que seria muito maior. A população ribeirinha do rio Madeira fica a mercê dos horários dos barcos e corre riscos com os ataques de jacarés, o que é comum na região.

No trajeto de Lábrea a Manaus pelo rio Purus existem muitas praias nas margens, que servem para contar o tempo de viagem. Entre Lábrea e Canutama, por exemplo, existem 53 praias, que orientam a população e o comandante do barco, pois se referem a elas para calcular quantas estão faltando para se chegar a cada localidade.

$\mathrm{Na}$ época das secas (verão) a viagem fica acrescida de 18 horas, a uma velocidade média de $18 \mathrm{~km} / \mathrm{h}$ no trecho Lábrea-Manaus. Não existe pressa no Amazonas.

As velocidades dos transportes estão diretamente relacionadas ao sentir as agruras do espaço a ser percorrido e, também, quanto mais lento é o transporte, mais se percebe o sofrimento e as necessidades da população. Como os tomadores de decisões se deslocam em altas velocidades, via área ou em lanchas "voadoras", supomos que não percebem as verdadeiras necessidades da população e as melhorias por elas exigidas não são tidas como reais, pois estes não são conhecedores do espaço vivido.

As enormes distâncias das áreas de produção aos centros consumidores provocam desperdício da produção, que chega a estragar; e também desmotivam os agricultores a ampliarem as suas roças.

As distâncias das comunidades e o pouco relacionamento com as sedes dos municípios faz com que se pratiquem preços das mercadorias em desalinho com os preços praticados nos mercados consumidores, permitindo também que haja exploração dos produtores por atravessadores e oportunistas, que não são poucos. Estes se deslocam de outros municípios e até mesmo de outros estados para aproveitar os baixos preços praticados, como no caso de Pauini. Enquanto o preço da farinha em Pauini é de $\mathrm{R} \$ 60,00$ a $\mathrm{R} \$ 80,00$ a saca de 60 quilos, em Coari a mesma saca é vendida entre $\mathrm{R} \$ 120,00$ e $\mathrm{R} \$ 150,00$.

Outra limitação ao desenvolvimento do modal hidroviário é o atraso nas saídas e chegadas. Vivenciamos isso em nosso trabalho de campo, quando o barco CMT Maia que saiu de Lábrea e deveria ter chegado a Manaus às 19 h do dia 6 de outubro de 2009, chegou no dia 8 , às 21 h. O atraso foi provocado pelo 

uma análise das microrregiões geográficas do Madeira e do Purus

dono do barco, para atender seus propósitos comerciais, e também para passar pela fiscalização da Capitânia de Manaus num momento mais adequado, já que fica mais vulnerável à noite. Esta prática comum é utilizada pela maioria dos donos de barcos.

Nos barcos que transportam passageiros e carga, a prioridade é sempre da carga.

$\mathrm{Na}$ maioria dos barcos em que navegamos, a higiene com a alimentação, com os compartimentos e acomodações eram precárias, mas a maioria dos comerciantes e vendedores da região preferem os barco, por viajarem junto com suas mercadorias e por terem maiores facilidades nas entregas.

Presenciamos, também, em Lábrea, podendo para o estado, o uso de balsas que fazem o transporte irregular de passageiros, devido à urgência e necessidade de deslocamento, mas não levam até Manaus, em função da fiscalização da Capitania. A fiscalização só existe nas proximidades de Manaus, dando espaço para os mais diversos tipos de ilícitos, inclusive de superlotação.

Para um percurso tão longo, como o do município de Lábrea até a capital Manaus, existem poucos barcos para atendimento à população: Comandante Maia, Cidade de Lábrea e Lindaura.

O modal rodoviário possui maior facilidade e velocidade de locomoção que o fluvial, mas no Amazonas os embarques ocorrem com maior frequência no modal fluvial, devido à localização da população às margens dos rios e também da precariedade do modal rodoviário, que não sobressai sobre o hidroviário - que tem velocidade limitada, mas grande capacidade de carga.

A principal rodovia federal do estado, a BR-319, segundo Fleck (2010), possui 885,4 km de extensão, sendo 859,5 km no estado do Amazonas, onde atravessa os municípios de Canutama, Humaitá, Tapauá, Manicoré, Beruri, Borba, Manaquiri, Careiro, Careiro da Várzea e Manaus. As condições atuais do pavimento e de trafegabilidade são variáveis. Os $165 \mathrm{~km}$ entre Careiro da Várzea (na margem direita do rio Amazonas) e Careiro (na margem do rio Tupãna) possuem asfalto em condições razoáveis de trafegabilidade. No entanto, os $500 \mathrm{~km}$ seguintes - até o entroncamento com a Rodovia Transamazônica (BR230) - encontram-se virtualmente intransitáveis, sem asfalto e com problemas em suas pontes e bueiros. A única manutenção vem sendo executada pela Embratel, para poder realizar e manter a ligação dos cabos telefônicos e de internet, que levam estes serviços para Manaus, como também a manutenção de pontes. A maior parte desse trecho também se encontra desabitada. $O$ trecho final de 180 km, entre Humaitá e Porto Velho, está pavimentado e em estado regular, mas com muitos buracos e com pontes de somente uma faixa, permitindo condições 
razoáveis de trafegabilidade (ÁRBOCZ et al., 2005; DNIT, 30/10/2008) (FLECK, 2010).

A BR 230 (Transamazônica) permite o acesso terrestre ao município de Apuí, e deste, pela AM 360, ao município de Novo Aripuanã.

Dentre as duas microrregiões estudadas, o município de Apuí é uma exceção, pois, segundo Valentim (2010), o município não fica às margens de nenhum rio navegável e as rodovias existentes se constituem na principal via de transporte. O acesso com o sul do país é feito através da Transamazônica, que devido à falta de manutenção, fica boa parte do ano completamente intransitável, causando sérios problemas para o município, como racionamento de energia elétrica, decorrente da falta de abastecimento de óleo diesel, e de altos preços nos produtos consumidos regularmente pela população.

Sobre as dificuldades da construção da BR-230 e dos reflexos da sua construção e uso no aproveitamento do modal hidroviário, achamos propício inserir neste espaço trechos da entrevista que realizamos com o Sr. Manoel Alves, comandante do barco CMT Maia, em 7 de outubro de 2009, e que ilustram a razão do uso dos barcos tanto para carga como para passageiros. Por ocasião do trabalho de campo, o Sr. Manoel nos disse que:

Quando eu vim para Lábrea, para morar com meus pais, em 1958, existiam 75 casas. Eu ajudei a fazer $60 \mathrm{~km}$ de picada sobre a várzea para prosseguir com a BR 230 além de Lábrea, mas era terreno inundável ou inundado e inviabilizava o aterro de um trecho tão longo, tanto é que não foi feito nada além disto, depois de Lábrea. Na época cheguei a cortar lenha para abastecer os 'batelões', que abasteciam com $50 \mathrm{~m}^{3}$ em Lábrea. Quando foi feito o trecho da BR 230 entre Humaitá e Lábrea parou de circular as balsas do Rio Madeira. Depois do abandono da BR 230 foi quando as balsas voltaram. A partir de 1975 começou o transporte mais intenso utilizando os atuais barcos recreios. A lancha da ENASA (do Governo) transportava borracha e pessoas, e era movida a lenha. A construção da BR 230 no estado do Amazonas foi no primeiro governo de Gilberto Mestrinho, o que foi errado, pois era uma obra do Governo Federal. A obra foi realizada pelo DERA e depois passou para o $5^{\circ} \mathrm{BEC}$.

Outro fato importante revelado pelo Sr. Manuel Alves é que a utilização da rodovia paralisou momentaneamente os serviços dos barcos de linha. Isto mostra que havia um interesse do governo estadual em se utilizar da rodovia, mas forças outras fizeram com que as rodovias ficassem inutilizadas e voltasse o transporte por barcos. Tanto é que, segundo o Sr. Manuel, só a empresa Passarão possui mais de 30 balsas que fazem o trajeto de Porto Velho para Manaus e viceversa, e a estrada praticamente paralisada no estado do Amazonas. 

uma análise das microrregiões geográficas do Madeira e do Purus

Na verdade, a volta dos barcos deveu-se à falta de manutenção e conclusão da rodovia, proposital ou não.

Os modais rodoviários e hidroviários apresentam, ainda, variáveis que devem ser analisadas. Ferreira (2010) nos revela a preocupação que se deve ter com a manutenção. Para a manutenção de uma rodovia, por exemplo, as obras teriam de ser feitas a cada nove anos; e numa hidrovia, a cada 30 anos. O prazo para retorno do investimento seria de 14 anos na rodovia e três anos na hidrovia. O custo do transporte seria de $\mathrm{R} \$ 94,70$ por tonelada a cada 1.000 quilômetros na rodovia e $\mathrm{R} \$ 42,00$ na hidrovia. O que na rodovia exigiria 200 carretas para transportar, pode ser levado no rio em um comboio de seis barcaças. Uma rodovia na Amazônia tem um custo maior de manutenção, um frete mais caro, uma menor capacidade de transporte e polui muito mais. Isso, sem considerar outros custos ambientais, como o incentivo ao desmatamento que uma rodovia produz na Amazônia.

Outro fator atraente do modal hidroviário é o preço dos fretes e das passagens, o baixo valor de manutenção das embarcações e das vias, enquanto as rodovias, que sofrem com as intempéries e desgastes associados à circulação dos veículos, logicamente necessitam de uma maior manutenção, redundando, assim, em mais gastos.

No Amazonas, o transporte aéreo é, em tese, complementar ao transporte fluvial, mas geralmente é o único modo de transporte permanentemente utilizável no território, por não sofrer as influências sazonais que sofrem alguns rios em sua perenidade.

As empresas que vêm atuando sobre no Sistema Aeroportuário do Amazonas priorizam os centros urbanos principais ou que são polos de desenvolvimento. O Plano aeroviário do estado do Amazonas de 1992 visava que o aeroporto, depois de implantado, começasse a sua utilização; e projetava que o impacto socioeconômico provocado ultrapassaria os limites de sua localidade, o que no Amazonas é muito lento, pelas características do próprio espaço, com grande extensão geográfica, população rarefeita, pouca industrialização etc., fato que aparentemente está dando certo. Dissemos aparentemente, porque muitas providências ainda são necessárias para a adequação do modal aeroviário no Amazonas, e destacamos os que atingem diretamente as microrregiões do Madeira e do Purus.

Nas microrregiões do Madeira e Purus houve melhorias nas construções das estações de passageiros, recapeamentos de algumas pistas de pousos e ampliação dos pátios de estacionamentos. São ações importantes porque o vetor aéreo é uma ferramenta essencial para a manutenção da lei e da ordem no estado 
do Amazonas no atendimento às missões das Forças Armadas, no atendimento à saúde, que são primordiais para as populações dos confins do estado, que estão à própria sorte.

A melhoria dos aeroportos permitiu que empresas como a Amazonaves, de Manaus, uma das companhias que prestam serviços de transporte aéreo, dobrasse seu movimento nos últimos cinco anos, com a entrega de insumos para a Petrobras e de bens de consumo como roupas, cosméticos, bicicletas, produtos eletrônicos e computadores para distribuidores locais (MARANHÃO, 2010).

A importância do modal aéreo, de acordo com Valentim (2010), pode ser observada no caso de Apuí, que devido a sua localização geográfica, apresenta-se como a principal via de acesso à capital do estado.

Mas esta situação de Apuí não beneficia diretamente a população, pois Valetim (2010) considera que como existe apenas uma empresa que presta este serviço no município, a população se obriga a pagar mais de $\mathrm{R} \$ 1.000,00$ (mil reais) para se deslocar até Manaus e retornar também pela via aérea. A empresa de aviação Apuí Táxi Aéreo é a única companhia de aviação a oferecer o serviço à população de Apuí.

Ainda existem outros problemas não menos importantes nas microrregiões do Madeira e do Purus, como a falta de homologação dos aeroportos, que desestimula a concorrência a destinar voos para os municípios, além do descumprimento às exigências dos órgãos responsáveis para a manutenção dos aeroportos.

Como a falta de fiscalização prevalece em todos os setores, também no setor aéreo permite que o garimpo ilegal e tráfico de drogas tirem vantagens.

Como se não bastasse, a população é desprovida de informações sobre os horários e disponibilidades de voos, e não existe nenhum apoio nos aeroportos localizados nas microrregiões do Madeira e Purus para a navegação aérea noturna.

Outra dificuldade é com o abastecimento, já que, além da capital Manaus, apenas quatro municípios - separados entre si por 3 horas de voo - têm estrutura para abastecer os aviões Caravan, que têm apenas 6 horas de autonomia de voo - o que é outro complicador. Mas, se as rodovias sofrem com buracos e as hidrovias com a falta de portos, o transporte aéreo padece com as chamadas “zonas escuras”, que não possuem cobertura de radar (MARANHÃO, 2010).

Após a caracterização das atuais condições de funcionamento e das possibilidades de uso dos modais de transporte no Amazonas, utilizamos dos estudos disponibilizados por Souza (2009) para mostrar os meios de transportes que dão acesso aos municípios do estado, as empresas operadoras, a frequência, os horários e locais de partidas. Estes dados servirão para breves comentários e 
análise do funcionamento do transporte em relação ao desenvolvimento regional, à saúde, educação e ao desenvolvimento social no Amazonas.

Informações recentes sobre os meios de acessos aos municípios, frequência, horários e empresas prestadoras de serviços de transporte de pessoas e cargas foram disponibilizadas por Souza (2009), onde destacamos os municípios das microrregiões do Madeira e do Purus.

Quadro 1: Microrregiões do Madeira e do Purus: meios de acesso aos municípios, frequência, horário e empresas prestadoras de serviços.

\begin{tabular}{|c|c|c|c|c|c|c|}
\hline \multirow[b]{2}{*}{$\begin{array}{l}\text { Microrre- } \\
\text { gião }\end{array}$} & \multirow[b]{2}{*}{ Município } & \multirow[b]{2}{*}{$\begin{array}{c}\text { Meio de } \\
\text { Transporte }\end{array}$} & \multirow[b]{2}{*}{ Empresa } & \multirow[b]{2}{*}{$\begin{array}{c}\text { Frequência/ } \\
\text { Semanal }\end{array}$} & \multicolumn{2}{|c|}{ Manaus/Município } \\
\hline & & & & & Local/Saída & $\begin{array}{l}\text { Horário/ } \\
\text { Saída }\end{array}$ \\
\hline Madeira & Apuí & Aéreo & $\begin{array}{l}\text { Apuí Taxi } \\
\text { Aéreo }\end{array}$ & $3^{a}$ e sábado & Eduardinho & $7 \mathrm{~h}$ \\
\hline Madeira & Borba & $\begin{array}{l}\text { Barco } \\
\text { Barco } \\
\text { Aéreo }\end{array}$ & $\begin{array}{l}\text { Ajato } \\
\text { Cometa } \\
\text { Haley } \\
\text { Rico }\end{array}$ & $\begin{array}{l}3^{\mathrm{a}} \text { e } 6^{\mathrm{a}} \\
6^{\mathrm{a}} \\
2^{\mathrm{a}}, 4^{\mathrm{a}} \text { e } 6^{\mathrm{a}}\end{array}$ & $\begin{array}{l}\text { Manaus } \\
\text { Moderna } \\
\text { Manaus } \\
\text { Moderna } \\
\text { Eduardinho }\end{array}$ & $\begin{array}{l}7 \mathrm{~h} \\
17 \mathrm{~h} \\
7: 30 \mathrm{~h}\end{array}$ \\
\hline Purus & Canutama & Barco & Manuel Silva & $6^{a}$ & \begin{tabular}{|l|} 
Manaus \\
Moderna
\end{tabular} & $18 \mathrm{~h}$ \\
\hline Madeira & Humaitá & $\begin{array}{l}\text { Aéreo } \\
\text { Barco }\end{array}$ & \begin{tabular}{|l|} 
Trip \\
Comandante \\
Moreira
\end{tabular} & $\begin{array}{l}3^{\mathrm{a}} \text { e sábado } \\
6^{\mathrm{a}}\end{array}$ & $\begin{array}{l}\text { Eduardinho } \\
\text { Porto de } \\
\text { Manaus }\end{array}$ & $\begin{array}{l}9: 30 \mathrm{~h} \\
18 \mathrm{~h}\end{array}$ \\
\hline Purus & Lábrea & Aéreo & Trip & $\begin{array}{l}\text { Domingo } \\
\text { e } 3^{\mathrm{a}}\end{array}$ & Eduardinho & 09:30h \\
\hline Madeira & Manicoré & $\begin{array}{l}\text { Aéreo } \\
\text { Aéreo } \\
\text { Barco }\end{array}$ & $\begin{array}{l}\text { Rico } \\
\text { Apuí Taxi } \\
\text { Aéreo } \\
\text { Vovô } \\
\text { Orlando }\end{array}$ & $\begin{array}{l}2^{a}, 4^{a} \text { e } 5^{a} \\
3^{a} \text { e sábado } \\
5^{a}\end{array}$ & $\begin{array}{l}\text { Eduardinho } \\
\text { Eduardinho } \\
\text { Manaus } \\
\text { Moderna }\end{array}$ & $\begin{array}{l}7: 30 \mathrm{~h} \\
7 \mathrm{~h} \\
18 \mathrm{~h}\end{array}$ \\
\hline Madeira & $\begin{array}{l}\text { Novo } \\
\text { Aripuanã }\end{array}$ & $\begin{array}{l}\text { Barco } \\
\text { Aéreo }\end{array}$ & $\begin{array}{l}\text { Ajato } \\
\text { Cometa } \\
\text { Haley }\end{array}$ & $\begin{array}{l}3^{\mathrm{a}} \mathrm{e} 6^{\mathrm{a}} \\
6^{\mathrm{a}}\end{array}$ & $\begin{array}{l}\text { Manaus } \\
\text { Moderna } \\
\text { Manaus } \\
\text { Moderna }\end{array}$ & $\begin{array}{l}7 \mathrm{~h} \\
17 \mathrm{~h}\end{array}$ \\
\hline Purus & Tapauá & Aéreo & $\begin{array}{l}\text { Apuí Taxi } \\
\text { Aéreo }\end{array}$ & $6^{a}$ & Eduardinho & $10 \mathrm{~h}$ \\
\hline
\end{tabular}

Fonte: Souza (2009). Adaptação do autor. 
Estudos da Secretaria do Estado de Educação do Amazonas (SEDUC, 2009), também apresentados por Souza (2009), confirmam as nossas observações quanto ao acesso aos municípios por barcos e por caminhões, para a distribuição de materiais escolares e merenda para as escolas estaduais. Os municípios de Apuí, Borba e Humaitá, na microrregião do Madeira, são acessados por rios e estradas, assim como o município de Canutama, na microrregião do Purus.

As dificuldades enfrentadas para o atendimento à educação são enormes e exigem desafios, e dentre os maiores estão a escassez de recursos e as grandes distâncias.

Detectamos, em conversas informais com professores da rede estadual de ensino, que estavam conosco nos vários barcos que utilizamos para o deslocamento em nosso trabalho de campo, que:

a) Os alunos que frequentam a escola, na maioria, têm menos de 18 anos de idade. Os com mais idade já estão trabalhando na pesca ou na agricultura;

b) Somente as escolas estaduais fornecem ensino médio grau;

c) $\mathrm{O}$ abandono escolar muitas vezes é devido à dificuldade de aprendizagem, que se considera como fracasso, e acontece mais a partir do $6^{\circ}$ ano.

d) Outro fator que chama a atenção é que não existindo mercado de trabalho, e inspirado nos seus pais e avós, os alunos não prosseguem seus estudos, mesmo os seus pais tendo o ensino médio. A desculpa é que se seus pais concluíram o nível médio e estão trabalhando na lavoura e na pesca, então, não precisam estudar;

e) A maioria dos empregos, inclusive os escolares, é gerada pelos municípios e pelo Estado;

f) O Seguro Defeso, o Bolsa Família e Auxílio Maternidade são grandes incentivadores para não se trabalhar;

g) Dentre os jovens não há motivação por aquisição de bens, principalmente na Zona Rural, por não ter o convívio com os bens;

h) Existem mais alunos na rede municipal, por ser ela que atende a Zona Rural;

i) A maioria dos professores é regida por contratos de um ano, que se renovam;

j) Mesmo próximo de Manaus, há um alto índice de analfabetismo;

k) A maioria da população ribeirinha possui "rabeta", mas raros são os que levam os filhos para a escola, por considerar que isto é uma função do município;

1) As aulas da manhã se estendem até às 9 h, horário da merenda, que é a maior motivadora dos alunos; 

uma análise das microrregiões geográficas do Madeira e do Purus

m) Quem mora nos ramais do município de Humaitá tem as piores situações de transporte, pois quando secam os igarapés e paranás não se consegue chegar e nem sair;

n) O transporte na Zona Rural chega a atingir mais de $70 \mathrm{~km}$ de distância;

o) Quando há atraso no pagamento, que é muito normal, pois atualmente os professores da rede municipal estão sem receber há mais de 3 meses, os fretados que fazem o transporte escolar também não recebem e também não fazem o transporte dos alunos;

p) Não há acompanhamento psicológico nas escolas dos municípios;

q) Em Manaus existe um tipo de educação; e no interior, outro;

r) É grande o número de adolescentes grávidas nas escolas;

s) Em Humaitá as escolas não são climatizadas, as de Manicoré são;

t) Qualquer atraso no pagamento dos fretados que realizam o transporte escolar eles paralisam os serviços, mesmo sabendo que vão receber depois;

u) O transporte fluvial propicia a entrega de materiais escolares e merendas provenientes de Manaus. O atraso implica no atraso do início das aulas, pois os alunos só vão às aulas se tiver merenda;

v) Manaus abastece as escolas de todos os municípios por barcos;

w) Os transportes passam, às vezes, a mais de $70 \mathrm{~km}$ de distância das escolas, exigindo que os alunos saiam de casa às $8 \mathrm{~h}$ para as aulas que iniciam às $13 \mathrm{~h} 15$ e terminam às $17 \mathrm{~h}$. $\mathrm{O}$ retorno ao lar se dá por volta das $20 \mathrm{~h}$. Isto não permite um bom rendimento dos alunos, devido à falta de tempo para a realização das tarefas. Isto provoca a evasão escolar;

x) $\mathrm{Na}$ rota do rio Madeira, a evasão após o $6^{\circ}$ ano é devido aos jovens terem que ajudar aos pais no garimpo;

z) Em Canutama, na rota do Purus, as aulas são interrompidas no verão e repostas aos sábados, no inverno, nas comunidades onde não existem Escolas Flutuantes.

O transporte por rodovias poderia reduzir uma série de problemas, e os aviões poderiam fazer o transporte de material escolar e de merendas, para evitar o atraso do ano letivo e também a evasão do início do ano.

Os dados nos revelam que mesmo tendo acesso pelo rio, nas escolas existem várias situações de ordem econômica e cultural que influenciam no desempenho escolar e na alfabetização.

Devemos levar em consideração também o que foi afirmado pelos professores em nossas conversas informais, ao revelarem que os municípios querem o ensino para receber arrecadação do FUNDEB. Em função deste 
benefício, existe a manipulação dos governos municipais no quantitativo de alunos por sala de aula.

Citamos apenas alguns problemas envolvendo a promoção da educação no estado do Amazonas, nas microrregiões selecionadas, dentre as inúmeras lacunas, como o atendimento quase que exclusivamente por barcos e, principalmente, com a falta de financiamento específico para a educação e saúde indígenas nos ramais e áreas ribeirinhas.

Apropriar-nos-emos dos dizeres de Tomazela (2010) para generalizarmos o que presenciamos e vivenciamos no estado do Amazonas em relação à saúde, principalmente nos municípios pertencentes às microrregiões do Madeira e Purus.

Tomazela (2010) afirma que no estado do Amazonas tem 6 mil médicos, mas só mil estão no interior.

Todo final de ano, as cidades enfrentam o que o prefeito de Nova Olinda do Norte, Adenilson Lima Reis (PMDB), chama de leilão da medicina. "Uma prefeitura oferece mais e tira o médico da outra." A carência de profissionais da saúde gera a invasão de médicos estrangeiros, sobretudo bolivianos e peruanos. São cerca de 200 no Estado, muitos sem o registro no Conselho Regional de Medicina. "São os únicos que aceitam trabalhar pelo valor que o governo repassa para o Programa Saúde da Família", (TOMAZELA, 2010).

As populações pobres, que vivem nos ramais ou ribeirinhas, dependem da própria sorte e de eventuais missões de ajuda para sobreviver. Há falta de médicos, hospitais e transporte, e ausência de saneamento básico, como água tratada, coleta de lixo e rede de esgotos.

Isto tudo nos remete aos dizeres de Sathler et al. (2009), que observam no Amazonas uma estrutura e hierarquia urbana aparentemente similar à das demais regiões do país, com centros regionais e locais claramente distinguíveis, em que os diversos níveis hierárquicos urbanos apresentam dinâmicas demográficas, socioeconômicas e espaciais distintas. A situação de fragilidade da rede urbana é mais enfática no estado do Amazonas, decorrente da criação de impedimentos para a circulação dos fluxos de pessoas, mercadorias, serviços, capitais e informações, cabendo destacar:

a) a grande proporção de população desprovida de recursos materiais e educacionais, decisivos no que tange a sua participação ativa nos diversos tipos de fluxos;

b) as grandes distâncias que separam as capitais das demais cidades e vilas; 

uma análise das microrregiões geográficas do Madeira e do Purus

c) a carência de infraestrutura nos setores de transporte e comunicação em grandes porções do território amazônico.

d) a limitada especialização das economias municipais e a consequente limitação e baixo dinamismo da atual divisão territorial do trabalho entre os municípios integrantes das microrregiões selecionadas.

No Amazonas, as grandes distâncias que separam os centros urbanos entre si e também da capital, aliadas à carência de infraestrutura adequada de transporte nos três modais que são possíveis no Estado: aeroviário, rodoviário e o fluvial, permitem aos agentes que disputam esse mercado tomarem decisões que impactam sobre a vida dos que deles se utilizam, sem se preocupar com suas consequências. Nos três modais, observamos que os interesses dos proprietários dos meios de transportes acabam por determinar a criação e extinção de linhas, a mudança de horários e de itinerários, e, na maioria das vezes, a priorização do transporte de cargas ao de pessoas. Esses agentes priorizam também o atendimento a certos centros urbanos em detrimentos de outros, como constatado durante a pesquisa sobre a utilização dos aeroportos do estado do Amazonas.

As questões singulares que caracterizam o Amazonas apontam a necessidade de ações gerais e específicas, de forma a adotar uma política estadual regional que combine ações e políticas implementadas nas escalas meso e microrregional, através da definição de programas específicos e de apoio das esferas estaduais. Muitos são os desafios de uma política de saúde para o Amazonas: alto crescimento demográfico; expansão de pequenos e médios municípios; pouco desenvolvimento institucional no processo de descentralização na área social (limitada autonomia e baixa qualidade da gestão); limitado impacto das mudanças no financiamento dos investimentos federais, geradores de mais governabilidade do que de equidade; e a persistente dificuldade de fixação de recursos humanos. A caracterização das situações geográficas no Amazonas possibilitou a identificação de múltiplas realidades que influenciam os serviços de atendimento à saúde e que teriam implicações diferentes para os processos de regionalização. Isso sugere não somente a necessidade de uma política regional única para o conjunto do estado, como a necessidade de várias políticas regionais, que possam articular estratégias para o desenvolvimento, proteção social e saúde (VIANNA et al., 2007).

Não podemos desconsiderar, na análise do estado do Amazonas, os acontecimentos havidos na Amazônia, pois as políticas foram pensadas durante décadas para uma Amazônia pretensamente homogênea, tanto para a sua integração como para a colonização. 
Ao considerarmos o desenvolvimento regional, principalmente nas microrregiões selecionadas, devemos considerar que existem nelas terras indígenas e seus ocupantes autóctones, as populações tradicionais e suas unidades de conservação, os produtores agrícolas, assentados ou não, os ribeirinhos e outros que necessitam de políticas públicas compensatórias.

Da Silva (2011) diz que o desenvolvimento não pode ser percebido unilateralmente a partir da produtividade, da capacidade de realização sistêmica dos produtos no âmbito dos mercados para a produção de riqueza.

Neste sentido, no Amazonas torna-se necessária a inversão da equação crescimento-desenvolvimento, priorizando pressupostos sociais, humanos e ambientais e não apenas quantitativos e econômicos. Aspectos como liberdade, cidadania, erradicação das desigualdades, empoderamento comunitário, respeito às diferenças, capital social e tantos outros estão sendo colocados como condição sine qua non para um desenvolvimento socialmente justo e ambientalmente sustentável (DA SILVA, 2011).

No que concerne à construção e estruturação de novas mentalidades na Amazônia brasileira, principalmente nas microrregiões do Madeira e do Purus, atuam nos municípios de Apuí, Canutama, Humaitá, Lábrea, Manicoré e Novo Aripuanã consórcios de organizações com o objetivo de fortalecer as entidades de classes locais, para que possam enfrentar problemas associados ao avanço da fronteira de desmatamento e aumentar o diálogo entre os diferentes atores para assegurar a conservação e o uso sustentável dos recursos naturais.

Estes consórcios surgem, de acordo com o IPAM (2011), a partir de demandas de organizações representativas, tais como a Coordenação das Organizações Indígenas da Amazônia Brasileira (COIAB), o Conselho Nacional dos Seringueiros (CNS), o Grupo de Trabalho da Amazônia (GTA) e a Coordenação das Organizações Indígenas da Bacia Amazônica (COICA) e suas organizações regionais e locais. O Instituto de Pesquisa Ambiental da Amazônia (IPAM) também organiza oficinas, seminários e capacitações na região Amazônica, em cidades, aldeias e comunidades, buscando formar multiplicadores, através de oficinas e seminários, tendo como foco principal a discussão da defesa e do fortalecimento dos direitos das populações, notadamente sobre seus territórios, e o papel das populações na conservação das florestas nativas e na contenção do desmatamento.

Todos esses esforços contribuem para a construção de um capital social, visto como uma rede de confiança e de compromisso mútuo, capaz de sedimentar vínculos de reciprocidade, cooperação, solidariedade e, acima de tudo, sentimento de pertencimento imprescindíveis no âmbito das lutas por um 

uma análise das microrregiões geográficas do Madeira e do Purus

desenvolvimento peculiar à condição do campo, ou seja, como uma Educação construtora e (re)afirmadora da racionalidade específica das pessoas que moram, trabalham, produzem, brincam, estudam etc., no campo (DA SILVA, 2011).

Mas, tratando-se de microrregiões localizadas dentro do território da cobiçada Amazônia, deve-se ater aos verdadeiros interesses que poderão estar por trás destas entidades, para que não levem, mais uma vez, a população à dependência histórica e desarticulada, sem levar em consideração as diversas territorialidades ali existentes.

\section{AGENTES SOCIAIS, MEIOS DE TRANSPORTE E USOS DO TERRITÓRIO NAS MICRORREGIÕES DO MADEIRA E DO PURUS: TENDÊNCIAS RECENTES}

As microrregiões do Madeira e do Purus são as expressões das relações econômicas e culturais do Estado, existindo ali, portanto, multiterritorialidades. As microrregiões vão se adequando ao "novo" que lhes é apresentado, mas estão abandonadas, quando nos baseamos nas constatações aqui apresentadas.

$\mathrm{Na}$ realidade, temos nas microrregiões a presença de diferentes agentes sociais, com distintos graus de autonomia econômica e política, de mobilidade e de capacidade de se apropriar dos resultados desse modelo de desenvolvimento, da mesma forma que esses diferentes agentes utilizam de modo desigual essas redes de transporte com distintas condições de circular, de se movimentar no território, portanto, com diferentes condições de se reproduzir socialmente, de acumular capital. Estamos aqui apontando os seguintes agentes: o Governo Federal, que utiliza as vias de transporte para alocação do seu pessoal, que na maioria das vezes são estranhos ao território, por pertencerem a diversos Estados do país; a Petrobras, que utiliza para o transporte de pessoal e de seus produtos; a empresas do ramo de exportação de soja do Grupo Maggi; os veículos da Empresa Passarão, que transporta diversos produtos de Porto Velho para Manaus e outros municípios do interior do Amazonas; o Grupo Bitolem, que também trabalha com o transporte de cargas em geral etc.

Certamente estes agentes não propiciam o desenvolvimento pleno da sociedade, pois, no bojo de suas ações encontra-se a motivação pelo lucro individual e a acumulação de riquezas.

A apropriação efetiva do território onde estão as microrregiões selecionadas fica à mercê dos diversos agentes que o utilizam com diversas finalidades, dando-lhe formas e funções especiais, de acordo com seus interesses e com o modo como utilizam as redes de transportes que os permeiam. 
As redes de transportes existentes nas duas microrregiões viabilizam as estratégias de circulação e de comunicação, mas não beneficiam diretamente à população local, pois utilizam o território como passagem, sendo, portanto, de pouca relevância para os espaços que ocupam, deixando neles os custos econômicos e ambientais. Assim as redes de transportes nas microrregiões selecionadas vão se adaptando às exigências do capitalismo, em diferentes épocas, com as várias formas de exploração, mantendo a sociedade com seus problemas crônicos, e até mesmo os aumentando, como é o caso da malária e o aumento da pobreza e indigência.

As políticas públicas direcionadas para estas microrregiões acabaram por propiciar a inserção de influências destruidoras sobre a sociedade, como as lutas pela terra e a destruição do meio ambiente, e muitas delas baseadas em ideias de intelectuais que incentivam a alimentar os mecanismos exploradores e seus esquemas econômicos.

Nas microrregiões, o uso dos barcos continua sem se modernizar, as rodovias não permitem que os transportes mais modernos percorram o território, em função das péssimas condições em que se encontram. Já no transporte aéreo, a modernização é constante, mas o uso proibitivo não auxilia a comunidade em geral, mas apenas alguns poucos segmentos da população.

Com estas observações, podemos afirmar que o uso do território e a sua integração intra e interregional continua através do modal hidroviário.

A lógica predominante das políticas públicas de transporte na instalação, modernização e regulação do uso dos diferentes modais propícios para as microrregiões do Madeira e do Purus (aéreo, hidroviário e rodoviário) visaram a integração inter e intrarregional do estado do Amazonas e da Amazônia brasileira como um todo, aos centros mais dinâmicos economicamente do país, além de numa função geopolítica, de ocupação, com uma maior influência do Brasil junto aos países amazônicos, numa necessidade de estreitar os laços com esses países (OLIVEIRA, 2000).

A lógica predominante é a de manter, através dos EIDs, os corredores de exportação de commodities, mas que não beneficiam as próprias microrregiões diretamente, mas sim a capital do estado e os maiores centros urbanos do país e do exterior.

Apesar da lógica racional original, Brito (1999) nos revela que um mar de irracionalidade foi o que restou quando cessaram as políticas desenvolvimentistas dos governos militares, pois faltou estrutura institucional e legal que evitasse os desperdícios, e os desvios de emprego e recursos destinados para a efetivação e otimização dos projetos. 

uma análise das microrregiões geográficas do Madeira e do Purus

As rodovias eram consideradas a mola mestra para o discurso geopolítico e também para a incrementação da Zona Franca de Manaus, para escoar a produção, e se traduziram no que Brito (1999, p. 218) considera como "os verdadeiros efeitos do modelo de desenvolvimento calcado no princípio da modernização forçada". Foram abandonadas e os agentes sociais priorizaram o rio para as suas diversas atividades, como constatamos e vimos na fala do Sr. Manuel, por ocasião do trabalho de campo.

Para evitar o descontinuísmo, o Plano de Aceleração do Crescimento (PAC 2007/2010) surgiu como iniciativa do Governo Federal com o objetivo de consolidar as ações que antes eram voltadas para a estabilidade macroeconômica. A aceleração do crescimento prevista no PAC é uma importante sistemática do Planejamento Governamental que orienta o que é urgente a ser executado no Plano Plurianual, em termos de infraestrutura. Aliado às propostas do PAC, surge o Plano Nacional de Logística e Transporte (PNLT), que além de um marco na retomada do processo de planejamento de longo prazo, em bases científicas, e um repositório de dados e avaliações estratégicas de inestimável valor, conjuga os diversos fatores associados ao cenário de crescimento da economia mundial e de estabilidade macroeconômica em nosso país. O PNLT tem o propósito de dar ao governo um conjunto de informações construídas e atualizadas que permitam escolher e priorizar soluções. Sem esse instrumento, o planejamento governamental permanecerá no "achismo" que caracterizou as últimas décadas (CARACIK Jr., 2007).

Embora não se possa comparar o PAC com o PNLT, no mínimo por causa de suas motivações extremamente díspares e pela visão de longo prazo deste, em relação ao curto prazo descolado daquele, fazem-se necessárias algumas considerações. O PNLT enfoca o Brasil em três tempos, procurando estabelecer um processo de planejamento estratégico, tanto nos princípios de estruturação, quanto no prazo de previsão e suas estações intermediárias. No entanto, em relação ao transporte hidroviário, investimentos em importantes corredores hidroviários, que possibilitariam uma alteração considerável na composição da matriz de transporte brasileira, estão previstos para um futuro que deveria ser hoje (CARACIK Jr., 2007, p. 54).

No estado do Amazonas, onde os corredores hidroviários são de fundamental importância, apenas a partir de 2016 é que a participação nos investimentos previstos passa a assumir a importância merecida. Mas é um modal considerado desprezado dentro dos investimentos previstos no PNLT, que para todo o país é de apenas 7,4\%, que é insuficiente para equilibrar a rede de transporte. O Amazonas será contemplado no trecho correspondente à hidrovia 
do Madeira que passa em seu território, principalmente na microrregião do Madeira (CARACIK Jr., 2007).

A hidrovia liga Porto Velho (RO) ao porto de Itacoatiara (AM), e por ela passam os fluxos atuais do escoamento das safras destinadas à exportação do Centro-Oeste. Também por ela descem os produtos do estado do Amazonas e da região, mas o uso restrito da hidrovia do Madeira mostra que não se utilizam adequadamente as demais hidrovias do Amazonas e da Amazônia, e assim obriga o grosso da produção a descer, por via rodoviária, trafegando enormes distâncias em busca dos portos de Santos e Paranaguá, a custos muito elevados.

Para Caracik Jr. (2007), o que está contemplado no PAC e no PNLT é somente o suficiente para recuperar o tempo perdido até aqui, mas, com certeza, não nos coloca à frente do processo de desenvolvimento tão acalentado.

Observamos que obras do PAC na BR-319, que liga Porto Velho a Manaus, no trecho que passa por Humaitá, na microrregião do Madeira, estavam sendo paralisadas. Estas obras estavam sendo executadas pelo Exército Brasileiro.

Foi nos dito por alguns funcionários que trabalhavam na recuperação da BR-319, nas proximidades do Posto Fiscal de Humaitá, que: “o IBAMA negou a licença ambiental para a continuação das obras, que o DNIT diz que não há mais verba para dar continuidade aos serviços".

$\mathrm{Na}$ configuração espacial atual da rede de transporte do Amazonas, as microrregiões geográficas do Madeira e do Purus continuam sendo as mais beneficiadas, por ser nelas que se encontram as únicas rodovias e um dos principais rios que permitem a integração do Amazonas com outros estados e com o exterior, isto sem falar que seus municípios possuem aeroportos que propiciam mais velocidades nas ligações internas e externas.

Os principais agentes que atuam nas microrregiões selecionadas são hegemônicos no transporte de pessoas e cargas pelos rios, que ainda permanece, em grande escala, o tradicional, sendo que alguns agentes utilizam da intermodalidade para alcançar seus objetivos.

A hegemonia no transporte hidroviário de cargas fica a cargo das empresas Bertolin, Grupo Maggi, e Petrobras, e outras de menor porte, mas que atuam nos mesmos segmentos, sendo que o entreposto dessas mercadorias se encontra fora delas e até mesmo fora do estado, como é o caso de Porto Velho (RO), Manaus e Itacoatiara.

Os usos atuais e os modelos existentes dos transportes permitem perceber que há fortes indícios de uma continuidade das microrregiões que não se beneficiam das ações para se alcançar os índices de desenvolvimento regional de outras regiões do próprio Estado, e muito menos das mais desenvolvidas do 

uma análise das microrregiões geográficas do Madeira e do Purus

país, porque têm seus territórios usados como passagem e meios de exploração que não trazem retorno para a melhoria da qualidade de vida da sua população.

Cabe aqui mencionar as críticas de autores como Egler (2008), Dupuy (1980), Offner (1993) e Silveira (2003) sobre o efeito estruturante da rede de transporte sobre o território, mostrando que a desigualdade está no centro do processo de criação de valor, e que a sociedade é guiada pelo lucro, e são dependentes de mercadorias; e o homem em si torna-se mercadoria e os recursos naturais são explorados de forma inconsequente.

No Amazonas, principalmente nas microrregiões do Madeira e do Purus, as diversidades dos caminhos que ligam os diversos pontos e territórios pelos quais não se podia dar "saltos", perdem-se.

Os transportes, especificamente nestas microrregiões, estão mergulhados em ambiguidades, não permitindo verificar a existência de uma causalidade linear entre os modais de transporte e o desenvolvimento regional, mesmo existindo entre as microrregiões selecionadas diferenças entre as redes de transportes referentes ao uso, distribuição, densidade de tráfego, funcionalidade e efetividade sobre o território, não provocando as transformações sociais, espaciais e econômicas que se traduziriam no desenvolvimento regional.

\section{CONCLUSÃO}

Tivemos limitações importantes para o desenvolvimento deste trabalho. Dentre elas, podemos citar a dificuldade de obtenção de dados sistemáticos ou que apresentassem uma série de registros pelos órgãos federados sobre os fluxos de mercadorias e pessoas nos três modais. A fiscalização é falha nas microrregiões estudadas e facilmente burladas pelos proprietários de veículos que utilizam as vias de transporte. Também tivemos limitações na obtenção de informações importantes nas entrevistas, por se tratarem de profissionais da educação e/ou ligados a empresas que atuam nas microrregiões selecionadas, que se limitavam nas informações para não se comprometerem. Também com limitações, identificamos os principais agentes sociais que utilizam os serviços de transportes, mas mesmo assim compreendemos a evolução e a dinâmica dos seus principais usos. Com estas limitações, as principais contribuições do artigo podem servir de agenda futura para outras pesquisas.

Este artigo ajudou-nos a entender que a dinâmica geopolítica e de integração territorial no estado do Amazonas estão presentes nestas duas microrregiões, a do Madeira e do Purus. Elas se misturaram e por força econômica se utilizaram e melhoraram seletivamente alguma via ou modal, e também algum centro urbano. 
Podemos dizer que a inserção das rodovias, aeroportos e melhoria das principais hidrovias das microrregiões selecionadas favoreceram a inserção do Brasil nos mercados globalizados, e a "desintegração competitiva" de outrora mantém seu caráter excludente e seletivo, não propiciando para que as microrregiões alcancem níveis estaduais e nacionais de desenvolvimento regional.

Os municípios que se destacam em nível estadual em alguns indicadores de desenvolvimento, nas microrregiões não mostram relações diretas com as infraestruturas de transportes existentes, mas com particularidades locacionais ou de apropriação do Governo Federal, visando à segurança nacional. Podemos citar como exemplo o caso de Apuí e Humaitá.

A dinâmica regional a que estão incluídas as microrregiões do Madeira e do Purus nos leva a dizer que não podem ficar à mercê das decisões de mercado para alcançar níveis sustentáveis de desenvolvimento regional, e que a presença do Estado, de forma articulada, pode deixar de ampliar as fraturas herdadas das microrregiões.

A análise da rede de transporte nos mostra que esta passa pelos territórios das microrregiões selecionadas, porém não se estabelecendo primeiramente nestas microrregiões, mas tem nelas suas origens ou ampliação. Manaus é o polo irradiador dos benefícios para as microrregiões, e até mesmo para Porto Velho (RO), que se situa fora do estado, faz o atendimento nos municípios mais ao sul das microrregiões do Madeira e do Purus.

Até mesmo a intermodalidade por nós presenciada na hidrovia do rio Madeira, não se faz no interior das microrregiões, mas se realiza em Manaus ou em Porto Velho. Desta forma, não há geração de emprego e renda, em função da utilização dos rios pelos grandes grupos exportadores e importadores. A maioria dos empregos existentes nas microrregiões é gerada pelos órgãos de governo, nas três instâncias administrativas.

As microrregiões do Madeira e do Purus se mostraram eficientes para a aplicação das políticas públicas que visaram aliviar as tensões sociais existentes em outras áreas do país, mas foram acometidas com as demandas e carências que estas populações necessitavam de onde vieram. As diversas políticas de transporte proporcionaram com que mais e mais elas ficassem aptas para atender à lógica de unificação dos mercados, e é o que vigora hoje em dia, e tende a se ampliar, como vimos nas propostas mais recentes como as do PAC e PNLT.

Concluímos que nas microrregiões geográficas do Madeira e do Purus a ação do homem para sustentar as vias rodoviárias e aéreas não consegue êxito através das políticas públicas, que são geradas distantes e por agentes sociais distantes da realidade do espaço em questão, e ainda provocam discórdias territoriais e prejuízos ao meio ambiente. 
O que as políticas públicas proporcionam é para que os usos dos circuitos naturais venham se aprimorando, mesmo que lentamente, e reforçam no consciente coletivo uma instabilidade e confiança, que se identificam cada vez mais com os transportes pelos rios das microrregiões.

Os aeroportos dos municípios que integram as microrregiões selecionadas são raramente utilizados pela população em geral, pois praticam preços proibitivos, e quando são utilizados, atendem aos governos municipal, estadual e federal.

Assim, podemos dizer que não existe uma rede de transporte que esteja efetivamente em uso nas microrregiões, e sim uma utilização maciça do modal hidroviário para o atendimento das infinitas necessidades da população.

Elas então continuam prisioneiras dos tempos de deslocamentos e da demora dos atendimentos dos serviços essenciais. A velocidade dos transportes está diretamente relacionada ao sentir as agruras do espaço. Quanto mais lento é o transporte, mais se percebe o sofrimento e as necessidades da população. Como os tomadores de decisões se deslocam em altas velocidades, supomos que não percebem as necessidades da população, e as melhorias por eles exigidas são tidas como reais, pois não são conhecedores do espaço vivido.

A utilização das rodovias só será viável se estabelecer uma intermodalidade nos centros urbanos das microrregiões, para o escoamento da produção do interior e atendimento à população, pois, do contrário, não podem competir com as ligações estabelecidas pelos rios, com o volume de carga e nem com os custos de passagens e de cargas.

Não observamos uma promoção de mudança social sustentável, com o propósito de progresso permanente de uma comunidade e seus membros. Neste espaço geográfico, o movimento do econômico e o movimento do social compõem movimentos contraditórios por natureza, e reforça o econômico, mesmo que haja uma forte intervenção do Estado na mediação das transformações históricas efetivas do desenvolvimento regional.

Ao afirmarmos que não se percebe o desenvolvimento regional nas microrregiões do Madeira e do Purus, é porque constatamos que a transformação, para ser observada, de acordo com: Frey e Wittmann (2006), Becker (2001), Ferreira (2002), Correa et al. (2009), Siedenberg (2004), Bandeira (1999) e Riella (2006), precisa considerar a esfera econômica do desenvolvimento regional que envolve: trabalho, natureza e organização produtiva enquanto mercadoria, ou melhor, enquanto produção e reprodução do capital; e a esfera social e ambiental que engloba: trabalho, natureza e organização produtiva enquanto vida, ou melhor, enquanto produção e reprodução da vida, sejam manifestadas nas mudanças estruturais ou qualitativas a partir de 'alterações endógenas'. 
As microrregiões selecionadas estão dentro dos fundamentos embutidos na Globalização, que é um forte fator exógeno que incide nas comunidades locais, e caracterizando o processo de desenvolvimento contemporâneo.

Foi observado, também, que os municípios das microrregiões do Madeira e do Purus não guardam relação direta entre o desenvolvimento regional, como conceituados e entendidos pelos diversos autores citados, com a existência em si da rede de transporte. Nelas, os transportes estão mergulhados em ambiguidades, mostrando as diferenças referentes ao uso, distribuição, densidade de tráfego, funcionalidade e efetividade sobre o território. Fatos que não provocam as transformações sociais, espaciais e econômicas que traduziriam no desenvolvimento regional.

Detectamos que os modais guardam uma relação com os usos do território e com as possibilidades de transporte e de circulação que a rede de transporte (rede e circuito), levando em conta as condicionantes naturais e institucionais, autoriza ou não se efetivar.

\section{REFERÊNCIAS}

ÁRBOCZ, G.; NALIATO, V.; REINECKE, W. Relatório de Vistoria Técnica. Empreendimento: rodovia BR-319, entre as cidades de Porto Velho, no Estado de Rondônia, e Manaus, no Estado do Amazonas, sob responsabilidade do DNIT - Departamento Nacional de Infra-estrutura de Transportes. Brasília, DF: COAIR; CGLIC; DILIQ;IBAMA, 2005.

BANDEIRA,P.S.Participação, articulação de atores sociaise desenvolvimento regional. Brasília, DF: IPEA, 1999. (Texto para Discussão, n. 630).

BARBOSA, M. M. R. C. Vantagens comparativas do transporte hidroviário. Estudo de caso. Agência Nacional de Transportes Aquaviários. São Paulo: [s.n], 2008. Disponível em:<http://www.aprosoja.com.br/novosite/ downloads/10102008110608.pdf>. Acesso em: 10 set. 2010.

BECKER, B. K. Revisão das políticas de ocupação da Amazônia: é possível identificar modelos para projetar cenários? Parcerias Estratégicas, Brasília, n. 12, p. 135-159, set. 2001.

BECKER, D. F. (Org.) Competitividade: o (des) caminho da globalização. Lajeado: FATES, 1998.

BERTOLINI, I. Transporte fluvial na Amazônia. In: SEMINÁRIO INTERNACIONAL SOBRE HIDROVIAS. 2007. Manaus. Anais... Manaus: ANTAQ, 2007. Disponivel em: http://www.antaq.gov.br/portal/pdf/Palestras/ PalestraBertolini.pdf>. Acesso em: 20 abr. 2011. 
BOISIER, S. Centralización y descentralización territorial en el proceso decisorio del sector público. Santiago: ILPES/CEPAL, 1995. (Documento CPRD, n. 95).

BRITO, D. C. A modernização da superfície: Estado e desenvolvimento na Amazônia. Belém: NAEA/UFPA, 1999.

CARACIK JÚNIOR, R. Panorama do setor da infra-estrutura logística do Brasil. In: CONFERÊNCIA NACIONAL DE INFRA-ESTRUTURA LOGÍSTICA. 2007. São Paulo. Anais...São Paulo, 2007.

CEPAL. E1 Regionalismo abierto en América Latina y el Caribe: la integración económica al servicio de la transformación productiva con equidad. Santiago: CEPAL, 1994.

Análise Ambiental e de Sustentabilidade do Estado do Amazonas.

Santiago: Nações Unidas, 2007. (LC/W.126.)

COMARA. Livro Histórico. Belém, 1996.

CONCEIÇÃO, A. L.; ROCHA, R. R. O Planejamento Regional: integrar para desintegrar. Scientia Plena, v. 5, n. 1, 2009. Disponível em: <www.scientiaplena. org.br>. Acesso em: 15 jan. 2011.

CONFALONIERI, U. E. C. Saúde na Amazônia: um modelo conceitual para a análise de paisagens e doenças. Estudos Avançados, São Paulo, v. 19, n. 53, 2005.

CORREA, S. M. S.; SAUER, K. E.; BACK, C. G.; COSTA, C. G. Sobre o Desenvolvimento Local de Territórios e Populações Marginais: o caso de Reservas Indígenas e áreas remanescentes de Quilombo no Vale do Taquari (RS). Disponível em: <http://www.ucdb.br/eventos/arquivos/UpFiles/362/fi le/ Karin_Elinor_Sauer.pdf>. Acesso em: 15 jan. 2009.

DA SILVA, J. B. Desenvolvimento, capital social, educação e populações do campo na Amazônia brasileira. Belém: [s.n.]: 2008. Disponível em: $<$ http:/ /www.artigonal.com/educacao-artigos/desenvolvimento-capital-socialeducacao-e-populacoes-docampo-na-amazonia-brasileira-1197161.html>. Acesso em: 20 jan. 2011.

DELGADO, N. G.; BONNAL, P.; LEITE, S. P. Desenvolvimento territorial: articulação de políticas públicas e atores sociais. Rio de Janeiro: IICA-OPPA; CPDA; UFRRJ, 2007. 
DNIT. $1{ }^{a}$ Unidade de Infra-Estrutura Terrestre - Amazonas. Disponível em: <http://www1.dnit.gov.br/rodovias/condicoes/am.htm>. Acesso em: 10 abr. 2010.

DNIT. Licitação para ponte sobre o Rio Madeira será aberta no próximo mês. Disponível em: <http://www.dnit.gov.br/noticias/mad>. Acesso em: 15 abr. 2010 .

DUPUY, J. P. Introdução à crítica da ecologia política. Rio de janeiro: Civilização Brasileira, 1980.

EGLER, C. A. G. Integração Econômica e Redes Logísticas no Cone Sul. UFRJ. Disponível em: < http://www.laget.igeo.ufrj.br/egler/pdf/Conesul.pdf>. Acesso em: 8 jul. 2008.

FERREIRA, E. Rodovias, ferrovias ou hidrovias na Amazônia? Novos caminhos. Disponível em: <http://ambienteacreano.blogspot.com/2009/08/ rodoviasferrovias-ou-hidrovias-na.html>. Acesso em: 2 jun. 2010.

FERREIRA, H. V. C. Programa de Desenvolvimento Integrado e Sustentável de Mesorregiões: uma experiência inovadora de desenvolvimento regional do governo brasileiro. In: CONGRESO INTERNACIONAL DEL CLAD SOBRE LA REFORMA DEL ESTADO Y DE LA ADMINISTRACIÓN PÚBLICA, 7., 2002. Lisboa. Anales... Lisboa: CLAD, 2002.

FIRJAN. Emprego em Renda nos Municípios do Estado do Amazonas (2000-2007). Disponível em: <http://www.fi rjan.org.br/data/pages/2C908CE 9229431C90122A3B25FA 534A2.htm>. Acesso em: 20 nov. 2010.

Ranking IFDM, 2007. Índice FIRJAN de desenvolvimento municipal. Manaus: FIRJAN, 2010b. Ano 3.

FLECK, L. C. Eficiência econômica, riscos e custos ambientais da reconstrução da rodovia BR-319. Disponível em: <http://conservationstrategy.org/fil les/CSF_Eficiencia_economica_BR319.pdf>. Acesso em: 15 set. 2010 .

FLECK, L. C. Eficiência econômica, riscos e custos ambientais da reconstrução da rodovia BR-319. [s.l.]: Conservação Estratégica - Brasil, 2009. 88 p. (Série Técnica, n. 17).

FREY, M. R.; WITTMANN, M. L. Gestão ambiental e desenvolvimento regional: uma análise da indústria fumageira. EURE [online], v. 32, n. 96, p. 99-115, 2006. ISSN 0250-7161. 
GOVERNO DO ESTADO DO AMAZONAS. Plano Diretor de Regionalização do Estado do Amazonas. Manaus: Secretaria de Estado da Saúde, 2003.

Mapa da Divisão Municipal do Estado do Amazonas, Brasil. Disponível em: <http://www.mapa-brasil.com/m_manaus_municipios.htm>. Acesso em: 15 jan. 2009.

Portal do Governo do Estado do Amazonas. Biblioteca virtual. Disponível em: <http://www.amazonas.am.gov.br/pagina_interna. php?cod=15>. Acesso em: 13 jan. 2010.

IBGE. Divisão do Brasil em mesorregiões e microrregiões geográficas. Rio de Janeiro: IBGE, 1990. v. I.

Divisão do Brasil em mesorregiões e microrregiões geográficas Região Norte. Rio de Janeiro: IBGE, 1991. v II.. t. 1.

Regiões de Influência das Cidades 1993. Rio de Janeiro: IBGE; Departamento de Geografia, 2000.

Censo demográfico. Brasília, DF: IBGE, 2000. Disponível em: <http://www.ibge.gov.br/ home/estatistica/populacao/censo2000/universo. php?tipo $=31$ \&paginaatual=1\&uf=13\&letra $>$. Acesso em: 5 nov. 2009.

Infraestrutura de transportes. Rio de Janeiro: IBGE, 2005.

Regiões de influência das cidades 2007. Rio de Janeiro: IBGE, 2008.

Mapa de Pobreza e Desigualdade - Municípios Brasileiros 2003. Disponível em: http://www.ibge.gov.br/estadosat/temas.php?sigla=am\&tema= mapapobreza2003>. Acesso em: 2 dez. 2009.

Sinopse do Censo Demográfico 2010. Disponível em: <http: / www. ibge.gov.br/estadosat/temas.php?sigla=am\&tema=sinopse_censodemog2010>. Acesso em: 8 jul. 2011.

IPAM. Povos indígenas e comunidades tradicionais: educação e empoderamento. Disponível em: < http://www.ipam.org.br/programas/projeto/ Povos-indigenase-comunidades-tradicionais-educacao-e-empoderamento/45>. Acesso em: 12 jan.2011.

IPEA. Amazonas: PIB das microrregiões geográficas, 1980-2000. Disponível em: <http://www.ipeadata.gov.br/ipeaweb.dll/ipeadata?SessionID=94045635\& Tick=1285259707328\&VAR_FUNCAO=Ser_Fontes $\% 28407 \% 29 \& \operatorname{Mod}=\mathrm{R}>$. Acesso em: 11 set. 2010. 
JELÉNYI, L. Panoramio. Disponível em: <http://www.panoramio.com/ user/4436370/tags/Nature>. Acesso em: 10 out. 2010.

JOIGNAUX, G.; BERION, P.; LANGUMIER, J. F. L'évaluation socioéconomique des infrastructures de transport: enrichir les approches du développement territorial. Revue d'Economie Régionale et Urbaine, Armand Colin, n. 4, p. 1-34, 2007.

LEMOS, M. B. Diretrizes para formulação de políticas de desenvolvimento regional e de ordenação do território brasileiro. Regionalização: análise da experiência brasileira recente. Belo Horizonte: FACE/CEDEPLAR-UFMG., 2004.

MARANHÃO, T. Logística na Amazônia: um longo e tortuoso caminho. Revista EXAME, 2008. Disponível em: <http://islog.org.br/home/?page_id=262>. Acesso em: 1 jun. 2010.

MINISTÉRIO DA EDUCAÇÃO. Região Norte: educação em debate. Disponível em: <http://portal.mec.gov.br/index.php?option=com_content\&v iew $=$ article\&id $=8889 \&$ catid $=223>$. Acesso em: 6 ago. 2010.

OFFNER. J. M. Les “effets struturants" Du transport: mythe politique, mystifi cation scientifi que. L'Espace Géografhique, n. 3, 1993, p. 233-242.

OLIVEIRA, J. A. Cidades na Selva. Manaus. Editora Valer, 2000.

Tempo e espaço urbano na Amazônia no período da borracha. Revista Electrónica de Geografía y Ciencias Sociales, Barcelona, v. 10, n. 218 (35), ago. 2006.

PERROUX, F. (1955). O conceito de pólo de desenvolvimento. In: SCHWARTZMAN, J. (Org.). Economia Regional: Textos Escolhidos. Belo Horizonte: CEDEPLAR/UFMG, 1977.

PERROUX, F. A economia do século XX. Lisboa: Herder, 1967.

RIELLA, A. Globalización, desarrollo y territórios menos favorecidos. Montevideo: Facultad de Ciências Sociales/Departamento de Sociologia, 2006.

SAE-Secretaria de Assuntos Estratégicos. Amazônia. Investimentos nas estradas vicinais. Brasília, DF: Presidência de República, 2009.

O poder aeroespacial na Amazônia Ocidental: situação atual (apoio logístico, monitoramento e controle, articulação, possibilidades e limitações) e perspectivas futuras. Reflexos para a Defesa Nacional. Disponível em: < http:/ / www.sae.gov.br/seminarioamazonia/wp-content/uploads/2010/08/ArtigoVII-COMAR.pdf>. Acesso em: 12 set. 2010. 

uma análise das microrregiões geográficas do Madeira e do Purus

SATHLER, D.; MONTE-MOR, R. L.; CARVALHO, J. A. M. As redes para além dos rios: urbanização e desequilíbrios na Amazônia brasileira. Nova Econ.[online], v. 19, n. 1, p. 11-39, 2009.

SEPLAN/AM-Secretaria de Estado de Planejamento e Desenvolvimento Econômico do Estado do Amazonas. Produto interno bruto dos municípios amazonense. Disponível em: <http://www.seplan.am.gov.br/downloads/ PIB_MUNICIPAL.pdf $>$. Acesso em: 7 jan.2009.

SEPLAN/AM-Secretaria de Estado de Planejamento e Desenvolvimento Econômico do Estado do Amazonas. Condensado de Informações sobre os Municípios do estado do Amazonas. 4. ed. Manaus: SEPLAN, 2004.

Síntese Econômica do Estado do Amazonas. Manaus: SEPLAN, 2006.

Perfil Municipal. Disponível em: <http://www.seplan.am.gov. br/arquivos/download/arqeditor/indicadores/perf_mun/Condensadov3/ Conteudo/subregiao6/7-gabriel.html>. Acesso em: 15 fev. 2009.

Produto Interno Bruto Municipal por Mesorregiões, Microrregiões Homogêneas e Municípios do Estado do Amazonas - 2002 / 2006. Manaus: SEPLAN, 2009a.

Anuário Estatístico do Amazonas - 2008. Manaus: SEPLAN, 2009c.

Condensado de informações sobre os municípios do Estado do Amazonas. 9. ed. Manaus: SEPLAN, 2011. Disponível em: < http://www. seplan.am.gov.br/arquivos/download/arqeditor/condensado_municipal_2010. pdf>. Acesso em: 5 maio 2011.

SIEDENBERG, D. R. Desenvolvimento: ambiguidades de um conceito difuso. Desenvolvimento em Questão, Ijuí, v. 2, n. 3, jan.-jun. 2004.

SILVA, A. Aeroportos e desenvolvimento. Rio de Janeiro; Belo Horizonte: Instituto Histórico-Cultural da Aeronáutica, Villa Rica Editoras Reunidas, 1991.

SILVA, R. S. Aeroportos na Amazônia: sua importância econômica na organização espacial do Estado do Amazonas. Belém: UNAMA, 2003.

SILVA, R. S. Políticas Públicas, rede de transporte e desenvolvimento regional no estado do Amazonas. 2011. Tese (Doutorado em Desenvolvimento Regional) - Universidade de Santa Cruz do Sul, 2011. 
SILVEIRA, R. L. L. Redes e território: uma breve contribuição geográfica ao debate sobre a relação sociedade e tecnologia. Revista Bibliográfica de Geografía y Ciencias Sociales, Barcelona, v. 8, n. 451, 15 jun. 2003. Disponível em: <http://www.ub.es/geocrit/b3w-451.htm> Acesso em: 5 maio 2011.

SOUZA, M. H. Contribuição metodológica para localizar terminal de integração de passageiros do transporte hidro-rodoviário urbano. 2009. 222 f. Tese (Doutorado em Engenharia de Produção em Transportes ) - COPPE, Universidade Federal do Rio de Janeiro, Rio de Janeiro, 2009.

TOMAZELA, J. M. Missão da FAB salva vidas na Amazônia. Disponível em: $<$ http:/ /www.fab.mil.br/portal/capa/index.php?datan $=31 / 05 / 2009 \&$ page $=\mathrm{m}$ ostra_notimpol>. Acesso em: 5 set. 2010.

VALENTIM, I. Avião faz pouso forçado em Apuí e repórteres indiscretos quase levama pior. Disponível em: <http://www.portalapui.com.br/index. php?option $=$ com_content\&view $=$ article\&id=87:pousoforcadoemapui\&catid $=$ 1:ultimasnoticias\&Itemid=50>. Acesso em: 9 out. 2010.

VIANNA, A. L. A.; MACHADO, C. V.; BAPTISTA, T. W. F.; LIMA, L. D.; MENDONÇA, M. H. M.; HEIMANN, L. S.; ALBUQUERQUE, M. V.; IOZZI, F. L.; DAVID, V. C.; IBAÑEZ, P.; FREDERICO, S. Sistema de saúde universal e território: desafios de uma política regional para a Amazônia Legal. Caderno de Saúde Pública, Rio de Janeiro, 2007.

WALTER FILHO. Técnicos da COMARA visitam o Aeroporto de Manicoré. Disponível em: <http://www.ocurumim.com.br/Noticia.asp?ID=1091>. Acesso em: 9 set. 2010. 